\title{
INTEGRATED MANAGEMENT OF ROOT-KNOT NEMATODE (MELOIDOGYNE SPP.) IN CUCUMBER (CUCUMIS SATIVUS L.) AND ITS EFFECT ON NEMATODE POPULATION DENSITY, PLANT GROWTH AND YIELD IN SULAIMANI GOVERNORATE, KURDISTAN, IRAQ
}

\author{
ISMAEL, J. H. S. ${ }^{1}-$ MAHMOOD, A. A. ${ }^{2}$ \\ ${ }^{I}$ Department of Horticulture, College of Agricultural Engineering Sciences, University of \\ Sulaimani, 46001 Sulaimani, Kurdistan Region, Iraq \\ ${ }^{2}$ Ministry of Agriculture and Water Resources, DAR/Sulaimani, Kurdistan Region, Iraq \\ *Corresponding author \\ e-mail: jalal.ismael@univsul.edu.iq \\ (Received $1^{\text {st }}$ Feb 2020; accepted $25^{\text {th }}$ May 2020)
}

\begin{abstract}
Samples of cucumber plants (Cucumis sativus L.) were collected from different locations of Bakrajo/Sulaimani governorate, Kurdistan region, Iraq. The collected plants were by stunting and yellowing while the roots with obvious root-knots. For nematode identification two methods were used for nematode identification, Perennial Patterns and PCR, with species-specific primers, showing that there were two species; Meloidogyne incognita (Kofoid \& White) Chitwood, and M. javanica (Treub) Chitwood. An experiment was designed, different methods have been used for controlling RKN, The results showed that after application of the above treatments whether alone or in combination, the minimum numbers of juvenile 2 (J2) were as well as in Nemakey, Humic acid and Chitosan combination treatment to be (66.33) recorded the maximum number after 30 days of application. Plant receiving combined treatments (Nemakey, Humic acid and Chitosan) significantly reduced the number of total nematode population at $(\mathrm{p} \leq 0.05)$ in comparison to controls. The minimum number of gall formation on the cucumber root system and galling index with the highest percentage of gall decreasing (23.76, 3.1 and $77.00 \%$ ) were revealed in case of combined treatments (Nemakey, Humic acid and Chitosan). A significant decrease $(\mathrm{p} \leq 0.05)$ of disease severity percentage was recorded under Humic acid and Chitosan treatment (66\%). The combination (Nemakey, Humic acid and Chitosan) also recorded vigorous growth and high yield. This paper is first scientific report about diagnosing and controlling the cucumber root-knot nematode in the region.
\end{abstract}

Keywords: Meloidogyne, species-specific primers, PCR, Nemakey, Chitosan, Besto humic, Rugby

\section{Introduction}

Cucumber (Cucumis sativus L.) is an economic crop considered as one of the most popular vegetables which ranked the fourth most important vegetable after tomato, cabbage and onion in the world, and belongs to the Cucurbitaceae family (Tatlioglu, 1993; Wehner and Maynard, 2003; Weng and Sun, 2011). It contributes in human health and it has an important role in antioxidant, metabolism processes. It contains lariciresinol, pinoresinol and secoisolariciresinol - 3 lignans which have a strong history of research in connection in reducing risks of several types of cancer including colon, breast, prostate cancer, uterine and ovarian cancers (Maheshwari et al., 2014).

In Iraq, cucumber is an important economical crop to the farmers and is widely cultivated in Summer depending on irrigation throughout the year (Soppe and Saleh, 2012). Estimates cultivated area with cucumber in Sulaimani governorate under protected cultivation is 602 ha. 
Plastic house are often used to obtain the highest production per unit area, which attains the most practical method of achieving the objectives of protected agriculture and is considered cropping technique where the environmental condition surrounding the plant is controlled partially/fully as plant need during their period of growth which target get maximum yield and resource saving (Nair and Barche, 2014).

Cucumber in plastic houses is attacked by many diseases that are caused by bacteria, fungi, viruses, and nematodes. But nematodes are the most important and causes yield loses (Agrios, 2005). Plant Parasitic Nematodes (PPNs) contribute limited production of vegetables, estimated annual losses caused by (PPN) more than US $\$ 100$ billion worldwide (Bird et al., 2008).

Most of the (PPN) that attack the roots of plants are Root-Knot Nematode (RKN). The most economically important genus which obligates plant roots is the genus Meloidogyne distributed worldwide. This genus includes 98 described species (Moens et al., 2009; Jones et al., 2013), and infect more than 2000 to 3000 species including almost all cultivated plants; including vegetables, fruit trees, oil crops, fiber crops, grains crops and leguminous crops. The most well-known species for genus Meloidogyne include Meloidogyne incognita M. incognita (Kofoid \& White) Chitwood, M. javanica (Treub,) Chitwood, M. arenaria (Neal), Chitwood and M. hapla Chitwood were of outstanding economic importance because they were responsible for at least $90 \%$ of all damage caused by root-knot nematodes (Castagnone-Sereno, 2002; Agrios, 2005).

The symptoms of infected plants by (RKN) appear in both aboveground and underground, aboveground shows poor growth, fewer and small pale green leaves that tend to wilt in warm weather, the quality and production always reduced result of fewer of blossoms and fruits. The underground symptoms appear by information galls on the roots which are two to several times as larger in diameter as the healthy root that impact of absorbing and translocating water and dissolved nutrients to the plants. The nematodes parasitize roots cause injuries, which facilitate entry by other soil-borne pathogens (Agrios, 2005).

Management of $(\mathrm{RKN})$ is often difficult and requires multiple and intensive efforts because they live in the soil and complete their life cycle inter plant tissues (endo-parasitic nature). At the same time, they have wide host ranges, short generation times, and high reproductive rates, however, discourage uses nematicides because they are highly toxic and contribute risk to human and animal health. In additional, they have negative influences on the environment (Abawi and Widmer, 2000; Trudgill and Blok, 2001; Hildalgo-Diaz and Kerry, 2008). Depending on single process to manage (RKN) is not often gives satisfactory results. Thus, a combination of management various techniques (Mesiha, 2019), generally provide acceptable management of (RKNs) and at the same time economic and eco-friendly method e.g. bioagent methods (Dong et al., 2012; Huang, et al., 2016), it is necessary promote techniques that aimed at integrated management to minimize their populations below the economic threshold level (Mitkowski and Abawi, 2003).

Although spread and distribution information of Root-Knot Nematode (RKN) species in Kurdistan especially in Sulaimani area is very little, yet, little work has been done to manage this disease. This work comes into request of the general directorate of Sulaimani Agricultural and Water Resources Office.

Therefore, this study is aimed to identify and diagnose of the nematode(s) Meloidogyne species based on morphological characteristics and molecular method which cause root-knot diseases of cucumber plant and its management by using different modern methods. 


\section{Materials and methods}

\section{Identification and diagnosis of root-knot nematode (RKN)}

For identification of the isolated RKNs two different methods were used: morphological characteristics (Perineal Patterns) according to (Hartman and Sasser, 1985). Three to four perineal patterns from a single population positioned on the slide with outer side uppermost and a glass cover slide applied (Taylor and Netscher, 1974; Taylor and Sasser, 1978; Eisenback and Hunt, 2009). The second method was molecular marker; species-specific primers have been prepared by (Sinacion, Bioscience Co. Iran), for identifying species of Meloidogyne as shown in Table 1. The extraction of DNA for Meloidogyne spp. and DNA amplification have been conducted at the Graduate Studies Laboratory- Animal Science Department - College of Agricultural Sciences, Sulaimani University.

Table 1. Species-specific primers used for Meloidogyne identification

\begin{tabular}{|c|c|c|c|c|c|c|c|}
\hline 1 & 2 & 3 & 4 & 5 & 6 & 7 & 8 \\
\hline $\begin{array}{c}\text { Primer } \\
\text { name }\end{array}$ & $\begin{array}{c}\text { OD } \\
(1000 \mu \mathrm{m})\end{array}$ & MW & nmol & $\begin{array}{c}\text { Water/tube } \\
(\mu \mathrm{l})\end{array}$ & TM & Seq. $\left(5^{-}-3^{-}\right)$ & mer \\
\hline AS1F & 7 & 6029 & 38.31 & 383.15 & 55.9 & CTCTGCCCAATGAGCTGTCC & 20 \\
\hline AS1R & 7 & 5410 & 42.70 & 426.99 & 50.3 & СTCTGCCCTCACATTAGG & 18 \\
\hline $\mathrm{AS} 2 \mathrm{~F}$ & 7 & 5939 & 38.90 & 388.95 & 53.2 & TAGGCAGTAGGTTGTCGGG & 19 \\
\hline AS2R & 7 & 6412 & 36.03 & 360.26 & 52.4 & CAGATATCTCTGCATTGGTGC & 21 \\
\hline $\mathrm{AS} 3 \mathrm{~F}$ & 6 & 6188 & 32.00 & 319.97 & 51.8 & GGGATGTGTAAATGCTCCTG & 20 \\
\hline AS3R & 7 & 5917 & 39.04 & 390.40 & 55.9 & CCCGCTACACCCTCAACTTC & 20 \\
\hline AS4F & 7 & 6117 & 37.76 & 377.57 & 55.9 & GTGAGGATTCAGCTCCCCAG & 20 \\
\hline AS4R & 7 & 6968 & 33.15 & 331.52 & 57.1 & ACGAGGAACATACTTCTCCGTCC & 23 \\
\hline AS5F & 7 & 6663 & 34.67 & 346.69 & 53 & CCTTAATGTCAACACTAGAGCC & 22 \\
\hline AS5R & 7 & 6110 & 37.81 & 378.07 & 49.7 & GGCCTTAACCGACAATTAGA & 20 \\
\hline AS6F & 7 & 6198 & 37.27 & 372.70 & 55.9 & GGTGCGCGATTGAACTGAGC & 20 \\
\hline AS6R & 7 & 7008 & 32.96 & 329.62 & 57.1 & CAGGCCCTTCAGTGGAACTATAC & 23 \\
\hline AS7F & 7 & 6102 & 37.86 & 378.56 & 53.8 & ACGCTAGAATTCGACCCTGG & 20 \\
\hline AS7R & 7 & 6136 & 37.65 & 376.47 & 55.9 & GGTACCAGAAGCAGCCATGC & 20 \\
\hline
\end{tabular}

\section{Molecular method}

In this study, species-specific primers have been prepared by (Sinacion, Bioscience Co. Iran), for identifying species of Meloidogyne as shown in Table 1. The extraction of DNA for Meloidogyne spp. and DNA amplification have been conducted at the Graduate Studies Laboratory- Animal Science Department - College of Agricultural Sciences, Sulaimani University.

\section{DNA extraction}

DNA of J2s and adult males isolated from soil were extracted by extraction-tray model (Thomas, 1958; Whitehead and Hemming, 1965). The females have been 
isolated from root tissue with sharp needle under stereo microscope. Therefore, J2s, males and female were collected with enough water in a tube that obtained by using standard technique $(1.5 \mathrm{ml}$ tube), the tube was put in a centrifuge (226R Refrigerated Universal Microcentrifuge, Labnet International Inc.) in $10000 \mathrm{rpm}$ for $3 \mathrm{~min}$ in order to precipitate nematodes down to the bottom of the tube, then excess water was removed from the upper part. An amount of $25 \mathrm{mg}$ from the precipitated nematodes was transferred to a slide and $20 \mu \mathrm{L}$ of ethanol was added, waited till dry then the precipitate nematodes were powdered by sharp needle under stereo microscope (ST-39 Series, Motic Co, United Kingdom). DNA of RKN was extracted utilizing AccuPrep ${ }^{\circledR}$ Genomic DNA Extraction Kit from (BIONEER) which involved isolation of DNA from mammalian tissue.

\section{Polymerase chain reactions (PCR) amplification}

Different primers were used for DNA amplification. The polymerase chain reactions (PCR) were carried out using the extracted RKN DNA as a template. Table 2 shows preparing different PCR reaction tube volume $(25 \mu \mathrm{L}$ and $50 \mu \mathrm{L})$ using the following ingredients.

The DNA samples were amplified using primers for two common species in separate PCR reactions. All PCR reactions were carried out in MUTIGENE OptiMAX machine, Labnet International Inc. (PCR Thermal Cycler). Similar PCR programs were used to identify Meloidogyne spp. (Powers and Harris, 1993; Zijlstra et al., 2000; Meng et al., 2004; Adam et al., 2007). The program has been changed and different annealing temperatures have been used for amplifying the DNA of the species according to the previous studies.

Table 2. Different ingredients amount used to complete $(25 \mu \mathrm{L}$ and $50 \mu \mathrm{L})$ of the PCR reaction tube volume

\begin{tabular}{c|c|c|c}
\hline Ingredients & Amount & Unit & Details \\
\hline Master Mix & $7.5,12.5$ and 25 & $\mu \mathrm{L}$ & Including of dATP, dCTP, dGTP, dTTP, Taq \\
DNA polymerase and PCR buffer \\
Sterilized distilled water & $4.5,7.5,12.5$ and 22 & $\mu \mathrm{L}$ & \\
Forward primer & 1 & $\mu \mathrm{L}$ & \\
Reverse primer & 1 & $\mu \mathrm{L}$ & \\
DNA extraction & 3,6 and 1 & $\mu \mathrm{L}$ & \\
\hline
\end{tabular}

\section{Gel electrophoresis}

The gel used for electrophoresis $(2.5 \%)$ was prepared by weighing out $2.5 \mathrm{~g}$ of agarose powder and dissolving in $100 \mathrm{ml}$ of $1 \mathrm{X}$ TBE buffer $(100 \mathrm{ml}$ of $10 \mathrm{X}$ TBE was diluted in $900 \mathrm{ml}$ of distilled water). The buffer was heated for $1 \mathrm{~min}$ in a microwave oven to dissolve the agarose powder and allowed to cool slightly $\left(55^{\circ} \mathrm{C}\right)$ before adding $6 \mu \mathrm{L}$ ethidium bromide. The mixture was poured into the electrophoresis chamber and allowed to cool. Combs with 16 and 13 teeth per row, were placed in the liquid agarose to make 16 and $13 \mu \mathrm{L}$ wells. Once the gel had solidified, the electrophoresis chamber was filled with sufficient $1 \mathrm{X}$ TBE buffer to cover the gel. Once the gel set, the combs were gently removed to avoid damaging the wells. The wells were loaded with $10 \mu \mathrm{L}$ of 
the PCR products mixed well with $3 \mu \mathrm{L}$ of $6 \mathrm{X}$ loading buffer and $6 \mu \mathrm{L}$ of DNA ladder was loaded into the left and right corner wells. The electrophoresis was run at 90-95 V and $65 \mathrm{~A}$ for $90 \mathrm{~min}$ to allow the separation of the fragments. The gel was placed in a UV transilluminator (Enduro ${ }^{\mathrm{TM}}$ GDS Touch, Labnet International Inc.). The gel pictures were digitally recorded and named with the sample number. DNA ladder (100-3000 bp) was used to approximate the size of the fragments. The size of bands on the gel was compared to the expected band size of Meloidogyne spp.

\section{Plastic house experiment}

Site study

The experiment was conducted in the plastic house during July- December 2015 in Bakrajo $2 \mathrm{~km}$ far from the College of Agricultural Sciences, Sulamani University. The plastic house is located on a latitude of $35^{\circ} 32^{\prime} 03.2^{\prime \prime} \mathrm{N}$ and longitude $45^{\circ} 21^{\prime} 15.7^{\prime \prime} \mathrm{E}$. GPS map (76CS, Garmin Co, Taiwan) had been used for this purpose.

\section{Site description and experimental design}

This study was conducted in the plastic house during $25^{\text {th }}$ July to $5^{\text {th }}$ December 2015. The total area of the plastic house $450 \mathrm{~m}^{2}(9 \times 50 \mathrm{~m})$. This experiment was carried out by using the Randomized Complete Block Design (RCBD) with three replicates, each replicate consisted of nine plots (experiment units) distributed to three rows, the area of each plot $=2.7 \mathrm{~m}^{2}(0.85 \mathrm{~m} \times 3.2 \mathrm{~m})$, the distance between plots was $1 \mathrm{~m}$ within one replicate, while $2 \mathrm{~m}$ was used between replicates, four pathways extend parallel to an along plastic house, the width of each pathway was $0.70 \mathrm{~m}$. The soil of the plastic house was naturally infected by RKN (Meloidogyne spp) and soil samples (1 kg) have been taken randomly prior the applying of the treatments for the chemical and physical analysis at the soil department laboratory/Sulaimani Agricultural Research Center. For watering the plants, dripping system was used. Another one $\mathrm{kg}$ of soil sample/plot was taken before and after applying treatments within three periods (10, 20 and 30 days of applying the treatments (100 $\mathrm{g}$ of soil was taken for each experimental unit (plot)). For preparing seedling of cucumber cv. Naseem F1, seeds were sown in a special place near the plastic house. After 10 days, the seedlings reached to appropriate length (2-3 leaves stage) were transplanted to the permanent place in the plastic house, all needed agricultural processes have been conducted for all plots and treatments.

\section{The physical and chemical properties of the greenhouse soil}

Physical and chemical soil analysis of the greenhouse soil prior treatments was conducted at the Sulaimani Applied Agricultural Research Center-Department of Soil and Water Resource/GDAWR, Ministry of Agriculture and Water Resources, KRG, Iraq (Table 3).

Table 3. Some physical and chemical properties of the greenhouse soil before applying the treatments

\begin{tabular}{|c|c|c|c|c|c|c|c|c|c|c|c|c|c|}
\hline $\begin{array}{l}\text { Soil } \\
\text { texture }\end{array}$ & $\begin{array}{c}\mathrm{EC} \\
\mathrm{dsm}^{-1}\end{array}$ & $\mathrm{PH}$ & $\begin{array}{l}\text { Total } \\
\mathrm{N} \%\end{array}$ & $\begin{array}{l}\text { Available } \\
\mathrm{P} \text { (ppm) }\end{array}$ & $\begin{array}{c}\text { Exch. } \\
\mathrm{K}+^{1} \mathrm{ppm}\end{array}$ & $\begin{array}{l}\text { Exch. } \\
\mathrm{Na}+^{1} \\
\mathrm{meq} / \mathrm{L}\end{array}$ & $\begin{array}{c}\text { Soluble } \\
\mathrm{Ca}^{2}{ }^{2} \\
\mathrm{meg} / \mathrm{L}\end{array}$ & $\begin{array}{l}\text { Soluble } \\
\mathrm{Mg}^{2} \\
\mathrm{meq} / \mathrm{L}\end{array}$ & $\begin{array}{c}\mathrm{Cl}^{-} \\
\mathrm{meq} / \mathrm{L}\end{array}$ & $\begin{array}{c}\% \\
\text { O.M }\end{array}$ & $\begin{array}{c}\% \\
\mathrm{CaCO} 3\end{array}$ & $\mathrm{HCO} 3$ & $\mathrm{CO}^{3}=$ \\
\hline Clay loam & 0.10 & 7.5 & 0.11 & 25 & 333.100 & 74.93 & 1.8 & 0.7 & 0.2 & 1.3 & 20 & 1.9 & 0 \\
\hline
\end{tabular}


Ismael - Mahmood: Integrated management of root-knot nematode (Meloidogyne spp.) in cucumber (Cucumis sativus L.) and its effect on nematode population density, plant growth and yield in Sulaimani Governorate, Kurdistan, Iraq - 4714 -

\section{The treatments}

In the plastic house, different chemicals and organic substrates were used alone and in combinations as follows:

1. Nemakey $1.5 \mathrm{ml} / \mathrm{m}^{2}$ (The soil sprayed thrice, 10 days interval was between the spraying 12-8-2015, 22-8-2015 and 1-9-2015, respectively).

2. Besto Humic (Humic acid15\%) $1.5 \mathrm{ml} / \mathrm{m}^{2}$ (the soil sprayed thrice, 10 days interval was between the spraying 12-8-2015, 22-8-2015 and 1-9-2015, respectively).

3. Chitosan (2\%) $1 \mathrm{~g} / 500 \mathrm{ml}$ water $\left(\mathrm{C}_{6} \mathrm{H}_{12} \mathrm{O}_{4}\right)$ n Assay $98 \%$ (The foliar sprayed twice, 10 days interval was between the spraying 26-8-2015 and 6-9-2015, respectively).

4. Nemakey $1.5 \mathrm{ml} / \mathrm{m}^{2}+$ Besto Humic (Humic acid15\%) $1.5 \mathrm{ml} / \mathrm{m}^{2}$.

5. Nemakey $1.5 \mathrm{ml} / \mathrm{m}^{2}+$ Chitosan $(2 \%) 1 \mathrm{~g} / 500 \mathrm{ml}$ water.

6. Besto Humic (Humic acid15\%) $1.5 \mathrm{ml} / \mathrm{m}^{2}+$ Chitosan $(2 \%) 1 \mathrm{~g} / 500 \mathrm{ml}$ water.

7. Nemakey1.5 ml/m² + Besto Humic (Humic acid15\%) $1.5 \mathrm{ml} / \mathrm{m}^{2}+$ Chitosan (2\%) $1 \mathrm{~g} / 500 \mathrm{ml}$ water.

8. Rugby® $100 \mathrm{ME} 1.6 \mathrm{ml} / \mathrm{m}^{2}$ chemical nematicide (positive control) (reference treatment) (The soil sprayed thrice, 10 days interval was between the spraying 12-8-2015, 22-8-2015 and 1-9-, respectively).

The manufacturers of the chemical as in Table 4 (all the chemicals were purchased from the local market).

\section{RKN population density}

One $\mathrm{kg}$ soil at the depth of $20-30 \mathrm{~cm}$ was collected from each plot and treatment, and mixed thoroughly, $100 \mathrm{~g}$ of this soil was taken at 12-8-2015 in order to calculate the no. of nematodes (J2) after applying the treatments, the process repeated for 10, 20 and 30 days. In order to isolate nematodes from the subsample soil $(100 \mathrm{~g})$ modified extraction-tray method was used according to (Thomas, 1958; Whitehead and Hemming, 1965), which the soil was placed on a double layer of paper towel (kitchen paper) supported by a metal buckle and placed over the extraction tray. Water was gently added to the tray until the soil was completely wet and then left for $48 \mathrm{~h}$ so that the nematodes would be washed down. counting dish digital hand counter and light stereo microscope (ST-39 Series, Motic Co. United Kingdom) 4× magnifications have been used to calculate the nematodes (Atamian et al., 2012; Bonuke, 2013).

\section{Reproduction factor $(R f)$}

The purpose of Reproduction factor (Rf) was to evaluate the effect of the different treatments on the population densities of the nematodes, if the recorded number was at least more than one, this means that the treatment had bad effect on the decreasing of the nematode population, while if the number was less than one, this means an excellent effect of the treatment was produced on the nematode densities. For calculating Rf the following equation was used (Timper et al., 2006; Lima et al., 2009).

$$
\text { Reproduction factor }(\mathrm{Rf})=\frac{\text { Final population of the nematodes }(\mathrm{Pf})}{\text { Initial population }(\mathrm{Pi})}
$$


Ismael - Mahmood: Integrated management of root-knot nematode (Meloidogyne spp.) in cucumber (Cucumis sativus L.) and its effect on nematode population density, plant growth and yield in Sulaimani Governorate, Kurdistan, Iraq

$$
-4715 \text { - }
$$

Table 4. The organic and chemical substrates were used in plastic house experiment

\begin{tabular}{c|c|c|c}
\hline No. & Trade name & Active ingredient & Manufacturer \\
\hline 1. & Nemakey & Organic & Merkez Anadolu Kimya Sanayi Co., Turkey \\
2. & Besto humic & Humic acid (15\%) & Organik Tarim Market Co., Turkey \\
3. & Chitosan $(98 \%)$ & N- acetyl- glucosamine* & Xi'an Lyphar Biotechnology Co., Ltd., China \\
4MC corporation, Agricultural Products Group, \\
Philadelphia, Pennsylvania, USA
\end{tabular}

\section{Root galling index (RGI)}

120 days after transplanting cucumber plant cv. Naseem F1 to permanent place, the plants were carefully uprooted from the soil in each plot and washed in running tap water to remove the adhering soil particles. After that the galls were removed from the root systems in each plant in order to calculate the number of the galls. From each plot 10 plants have been taken. For root gall index evaluating standard scale has been used as described by Taylor and Sasser (1978) shown in Table 5, for calculating disease severity and gall index the equations below has been used according to Zewain (2014), the percentage of gall decreasing also has been calculated equations (Kesba and AlShalaby, 2008).

$$
\begin{gathered}
\text { Disease severity }(\%)=\frac{\mathbb{E} \text { (Na.of galled plantsx its galling degree })}{\text { Total galled plant na. xhighest galling degree }} \times 100 \\
\text { Gall index }=\frac{\mathbb{E} \text { (No.of galled plantsx its galling degree) }}{\text { Total galled plant }} \\
\text { Gall reduction }(\%)=\frac{\text { (Control 2) }- \text { Treatment }}{\text { (Control 2) }} \times 100
\end{gathered}
$$

Table 5. Standard scale of Root-knot index

\begin{tabular}{c|c}
\hline Root-knot index & Number of galls/root system \\
\hline 0 & 0 \\
1 & $1-2$ \\
2 & $3-10$ \\
3 & $11-30$ \\
4 & $31-100$ \\
5 & $>100$ \\
\hline
\end{tabular}

\section{Plant growth and yield parameters}

For calculating each parameter 10 plants have been used from each experimental unit (plot), for vegetative system; plant height $(\mathrm{cm})$, stem diameter $(\mathrm{cm})$, no. of nodes/plant, no. of leaves/plant, fresh weight (gm/plant), \% of dry weight of vegetative parts and leaf area $\left(\mathrm{cm}^{2}\right)$ have been measured. For root system; root length $(\mathrm{cm})$, at the end of the seasons, the root system was extracted manually for the representative plants, then main root length $(\mathrm{cm})$ was measured from the crown zone to its farthest point using the metric tape, and fresh and dry root weights (gm/plant) have been calculated. Leaf chlorophyll (9 leaves of each 10 plants randomly selected) (Romero et al., 2012), Leaf chlorophyll 
intensity (SPAD unit) (Konica-Minolta, Osaka, Japan) (Coste et al., 2010), and leaf NPK content also calculated. For yield parameters; no. of aborted flowers/plant, no. of setting flowers/plant, fresh weight of fruits $(\mathrm{gm} / \mathrm{kg})$, diameter and length of fruits and moisture content, vegetative ratio (w/w), and finally the $\%$ of increased yield has been calculated for each treatment. The followings are the formula of the measured and calculated growth and yield parameters.

$$
\begin{aligned}
& \text { Dry vegetative parts weight }(\%)=\frac{\text { Dry weight (g) }}{\text { Fresh weight }} \times 100 \text { (Van De Sande }- \text { Bakhuyzen, 1928) (Eq.5) } \\
& \text { Fruit moisture content }(\%)=\frac{\text { Fresh fruit weight }- \text { Dry fruit weight }}{\text { Fresh fruit weight }} \times 100 \text { (FAO, 2013) (Eq.6) } \\
& \text { Vegetative/fruit ratio }(w / w)(\%)=\frac{\text { Fresh plant weight (vegetative part) }}{\text { Total harvested fruit (total pield) }} \times 100 \\
& \text { Percentage of increased yield }(\%)=\frac{\text { Yield (weight) of a treatment }- \text { Yield (weight) of control }}{\text { Yield (weight) of control }} \times 100 \quad \text { (Hasabo and Noweer, 2005) }(\text { Eq.8) }
\end{aligned}
$$

\section{Statistical analysis}

Randomized Complete Block Design (RCBD) was used in this study, the treatments repeated thrice (three replicates) (Crotty et al., 2009; Machado et al., 2014), the data were analyzed using XLSTAT program version 7.5 (XLSTAT, 2004). For the comparisons between means, Least Significant Difference (LSD) at the probability level of 5\% was used (Williams and Abdi, 2010; Chapuis-Lardy et al., 2015).

\section{Results}

\section{Identification and descriptions of isolated Root-Knot Nematodes (RKNs)}

One of the most important purposes of this study was to identify and put light on RKN Meloidogyne species present in the galls of the infected cucumber cv. Naseem F1 roots which was grown in the plastic house Bakrajo region. During isolation process the females of RKN from infected cucumber roots under stereo microscope, two species have been recorded Meloidogyne incognita and Meloidogyne javanica (Fig. 1A, B, C). The mature females of $M$. incognita under stereo microscope have a spherical shaped body, short projecting neck and white color (Fig. 1A, B).

\section{Morphological characteristics (perineal patterns)}

The perineal patterns observed under light microscope (Fig. 2A) very closely resembled to the descriptions of $M$. incognita which typically high with square-like dorsal arch. Lateral field weakly demarcated by breaks and forked striae. Striae were distinct and wavy. Dorsal striae smooth, closely placed wavy to zigzag that appear the dorsal and ventral striae are interrupted and forked at the lateral line.

\section{Molecular identification}

Accurate identification of RKN was obtained using molecular characteristics. Specific primers of $M$. incognita and $M$. javanica were used to amplify DNA fragment for all sample tested including J2s, males and females of Meloidogyne obtained from 
plastic house. The extracted DNA was visualized using Agarose gel and then the concentration of DNA was tested by Nanodrop 2000C device.
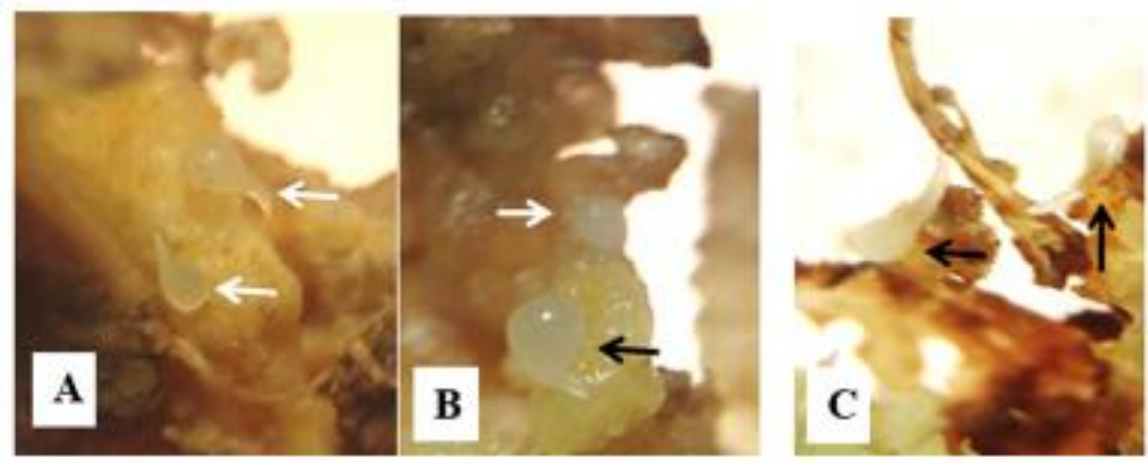

Figure 1. Stereo microscope photograph of female M. incognita $(A),(B)$ and female of $M$. javanica $(C)$ from infected cucumber root tissue (galls)
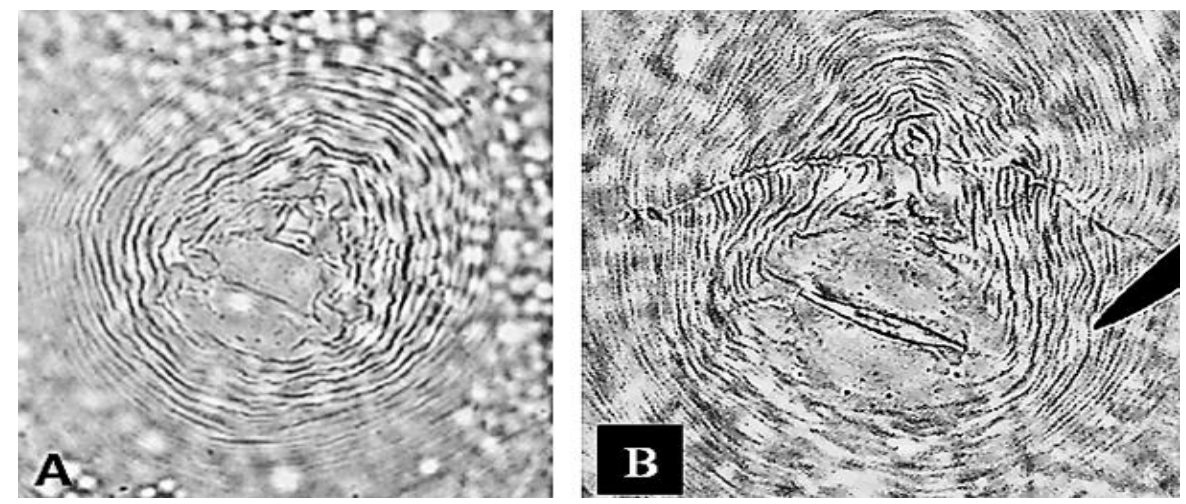

Figure 2. Perineal pattern of $(A) M$. ingonita and $(B)$ M. javanica under light stereomicroscope (Binocular Digital Compound Microscope (X400))

The procedure of DNA amplification has been performed six times and all pair primers were set up according to the annealing temperature for first and second times that mentioned by the manufacture company (Sinacion, Bioscience Co. Iran). The DNA samples were run again with all seven primers. They were set up according to the denaturation and annealing temperature conducted by previous studies. The ingredients amount of PCR reaction tube volume $(25 \mu \mathrm{L}$ and $50 \mu \mathrm{L})$ has been changed in every time.

Significant result of DNA amplification was able to be obtained using annealing temperature of $49^{\circ} \mathrm{C}$ and $50 \mu \mathrm{L}$ of the PCR reaction volume. Master mix, sterilized distilled water, forward primer, reverse primer and DNA extraction were 25, 22, 1, 1 and $1 \mu \mathrm{L}$ in size respectively when tested on agarose gel (Figs. $3 A, B$ and $4 A, B$ ).

The fail in obtaining positive result for both species using, AS2F AS2R, AS4F AS4R, AS5F AS5R primers might be refer to the specificity of these two races of nematodes used in the current study, being different from those used for other investigations. The occurrence of genetic mutation and the variation due to mating system in the species might made the primers to misplacing the flanked region of target fragment on the species DNA. 

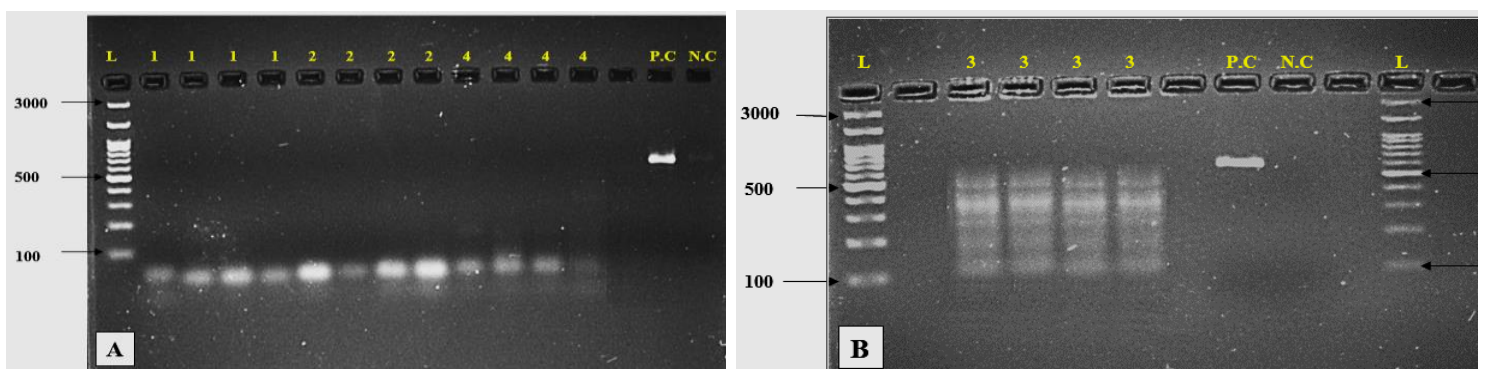

Figure 3. PCR products. (A) Extracts DNA amplified using species-specific primers name of primer $1=A S 1,2=A S 2,4=A S 4(1200 \mathrm{bp}, 1350 \mathrm{bp}$, and $955 \mathrm{bp})$ respectively for $M$. incognita, $L=D N A$ ladder $(100-3000 \mathrm{bp})$. P.C = Positive control, $N . C=$ Negative control. (B) Extracts DNA amplified using species-specific primers $3=A S 3 F$ AS3R $(399$ bp), for M. incognita. $L=$ DNA ladder (100-3000 bp). P.C = Positive control,

$$
\text { N.C }=\text { Negative control }
$$

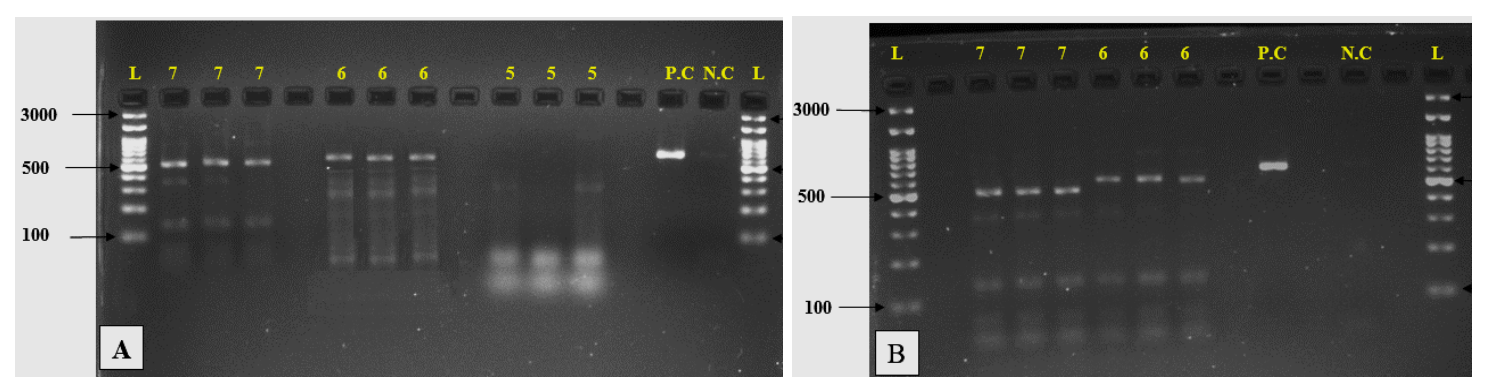

Figure 4. PCR products. (A) Extracts DNA amplified using species-specific primers name of primer $7=A S 7,6=A S 6,5=A S 5(517 \mathrm{bp}, 670 \mathrm{bp}$ and $1650 \mathrm{bp})$ respectively for $M$. javanica, $L=$ DNA ladder $(100 \mathrm{bp}-3000 \mathrm{bp}), P . C=$ Positive control, N.C = Negative control. (B) Extracts DNA amplified using species-specific primers $7=$ AS7, $6=$ AS6 respectively for $M$. javanica, $L=D N A$ ladder (100 bp-3000 bp), P.C = Positive control,

$$
\text { N.C = Negative control }
$$

\section{Nematode population density}

Population densities of root-knot nematode (Juveniles 2) in the soil before and after treatment application

In the plastic house experiment, different treatments have been used in order to investigate their influence on controlling the population densities and numbers of juveniles 2 before applying the treatments and after 10, 20 and 30 days. Table 6 shows that at $(\mathrm{p} \leq 0.05)$ the minimum numbers of juveniles $2(\mathrm{~J} 2 \mathrm{~s})$ were in using (Nemakey, Humic acid and Chitosan) which was (66.33), while maximum number of nematodes observed control $(1+2)$. There were significant differences among the treatments $(\mathrm{P} \leq 0.05)$ with the control 2. On the other hand, there were no significant differences among the treatments and control after 10 and 20 days (Table 6 ).

The present results show an approach to control $M$. incognita and $M$. javanica in cucumber plant using modern methods and more active for controlling Meloidogyne which are safer than nematicides. These results should be considered during designing an integrated pest management program for RKN or other nematode pathogens in cucumber and other crops. 
Ismael - Mahmood: Integrated management of root-knot nematode (Meloidogyne spp.) in cucumber (Cucumis sativus L.) and its effect on nematode population density, plant growth and yield in Sulaimani Governorate, Kurdistan, Iraq - 4719 -

Table 6. Effect of different treatments for controlling root-knot nematode (Meloidogyne spp.) on population densities (Juveniles 2)

\begin{tabular}{c|c|c|c|c}
\hline \multirow{2}{*}{ Treatment sets } & \multicolumn{4}{|c}{ Population densities (Juveniles 2) / 100 g soil } \\
\cline { 2 - 5 } & $\begin{array}{c}\text { One day before applying } \\
\text { treatments (Pi) }\end{array}$ & $\begin{array}{c}\text { After 10 days of } \\
\text { application }\end{array}$ & $\begin{array}{c}\text { After 20 days of } \\
\text { application }\end{array}$ & $\begin{array}{c}\text { After 30 days of } \\
\text { application (Pf) }\end{array}$ \\
\hline Nemakey & $163.00 \mathrm{a}$ & $234.33 \mathrm{ab}$ & $192.33 \mathrm{a}$ & $151.66 \mathrm{c}$ \\
Besto Humic & $152.00 \mathrm{a}$ & $321.66 \mathrm{ab}$ & $222.00 \mathrm{a}$ & $140.00 \mathrm{~cd}$ \\
Chitosan & $123.66 \mathrm{a}$ & $296.00 \mathrm{ab}$ & $310.33 \mathrm{a}$ & $301.66 \mathrm{~b}$ \\
Nemakey + Besto Humic & $180.66 \mathrm{a}$ & $312.66 \mathrm{ab}$ & $348.00 \mathrm{a}$ & $125.33 \mathrm{~cd}$ \\
Nemakey + Chitosan & $208.66 \mathrm{a}$ & $264.33 \mathrm{ab}$ & $330.00 \mathrm{a}$ & $133.00 \mathrm{~cd}$ \\
Besto Humic + Chitosan & $141.66 \mathrm{a}$ & $235.33 \mathrm{ab}$ & $447.00 \mathrm{a}$ & $120.66 \mathrm{~cd}$ \\
Nemakey + Besto Humic + Chitosan & $133.33 \mathrm{a}$ & $227.66 \mathrm{ab}$ & $508.00 \mathrm{a}$ & $66.33 \mathrm{~d}$ \\
Rugby® 100 ME (Control 1) & $148.33 \mathrm{a}$ & $150.00 \mathrm{~b}$ & $197.00 \mathrm{a}$ & $363.33 \mathrm{~b}$ \\
Water (Control 2) & $159.66 \mathrm{a}$ & $592.66 \mathrm{a}$ & $503.66 \mathrm{a}$ & $587.33 \mathrm{a}$ \\
LSD (P $\leq$ 0.05) & $101.75 \mathrm{u}$ & $403.02 \mathrm{u}$ & $464.49 \mathrm{u}$ & $80.87 \mathrm{u}$ \\
\hline
\end{tabular}

Data followed by the same letter in each column are not significantly different according to (LSD) test

\section{Reproduction factor $(R f)$}

Data in Figure 5 illustrate the impact of Nemakey, Humic acid and Chitosan alone or in combination comparing to Rugby ${ }^{\circledR} 100 \mathrm{ME}$ as (Control 1) and spray water only as (control 2) on reducing Meloidogyne incognita and Meloidogyne javanica which infected cucumber plant (cv. Naseem F1) under plastic house condition. Results revealed that reproduction factor (Rf) was adversely affected by treatments whether alone or in combination. It has been considered the best significant treatment was the three combinations (Nemakey + Best Humic (Humic acid 15\%) + Chitosan), the Rf value was less than one, although the others (Nemakey, Humic acid 15\%), (Nemakey + Chitosan 2\%), and (Humic acid15\% + Chitosan 2\%) treatments gave the same result, that mean the efficacy of the treatments in reducing the population density of root-knot nematodes (Juveniles 2).

\section{Root gall index $(R G I)$}

Data presented in Table 7 show the influence of various treatments Nemakey, Humic acid and Chitosan whether alone or in combination in comparison to with controls $(1+2)$ against RKN which infected cucumber crop (cv. Naseem F1) under plastic house condition.

Results indicated that all treatments obviously were reducing the number of gall index, disease severity percentage and percentage of gall decreasing (reduction). Among the treatments, combined treatments (Nemakey + Humic acid + Chitosan) recorded (23.76) of reducing the gall formation on the root system of the cucumber crop and achieved higher significant $(\mathrm{p} \leq 0.05)$ with the highest percentage of gall decreasing $(77.00 \%)$ and found to be the most effective, since it reduced the number of galls more than those of the other treatment, followed by (Nemakey + Chitosan) (39.40 galls/plant, 61.86\% reduction) and (Humic acid + Chitosan) (39.90 galls/plant, $61.38 \%$ reduction) as compared with controls $(69.46,103.33,32.77 \%$ reduction) respectively. Minimum galling index (3.1) was recorded when the cucumber plant was treated with combined of (Nemakey, Humic acid and Chitosan) followed by (Humic acid and chitosan) (3.3) and (Nemakey and Humic acid) (3.6) as compared to controls (4.1 and 4.5) respectively. 


$$
-4720-
$$

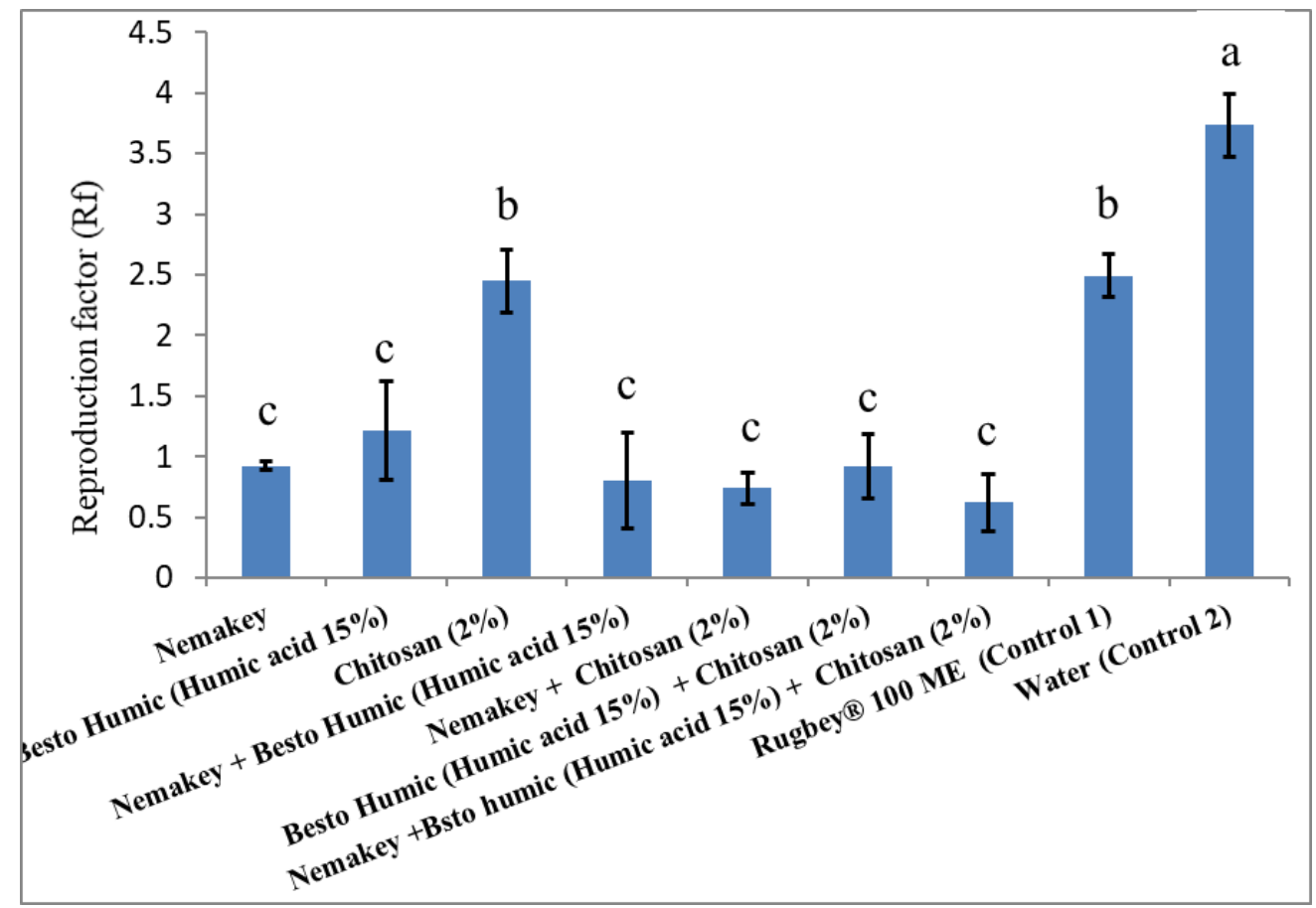

Figure 5. Effect of different methods of controlling on reproduction factor (Rf) after 30 days of calculating the no. of the nematodes (juveniles 2). The bars refer to the standard errors (SE) at

$$
(P \leq 0.05)
$$

Table 7. Effect of different treatments for controlling root-knot nematode (Meloidogyne spp.) on number of galls in the roots of cucumber (cv. Naseem F1)

\begin{tabular}{c|c|c|c|c|c}
\hline \multirow{2}{*}{ Treatment sets } & \multicolumn{2}{|c|}{$\begin{array}{c}\text { Means of number of } \\
\text { the galls }\end{array}$} & \multirow{2}{*}{ Gall index } & $\begin{array}{c}\text { Disease } \\
\text { severity \% }\end{array}$ & $\begin{array}{c}\text { \% of gall } \\
\text { decreasing }\end{array}$ \\
\cline { 2 - 5 } & $\begin{array}{c}\text { Average } \\
\mathbf{0 . 0 5}\end{array}$ & $\begin{array}{c}\text { Average } \\
\mathbf{0 . 0 1}\end{array}$ & & & \\
\hline Nemakey & $50.29 \mathrm{bc}$ & $50.29 \mathrm{bc}$ & 3.70 & 74.00 & 51.33 \\
Besto Humic & $50.86 \mathrm{bc}$ & $50.86 \mathrm{bc}$ & 3.90 & 97.50 & 50.77 \\
Chitosan & $54.23 \mathrm{bc}$ & $54.23 \mathrm{bc}$ & 3.90 & 78.00 & 47.51 \\
Nemakey + Besto Humic & $40.40 \mathrm{~cd}$ & $40.40 \mathrm{bc}$ & 3.60 & 90.00 & 60.90 \\
Nemakey + Chitosan & $39.40 \mathrm{~cd}$ & $39.40 \mathrm{bc}$ & 3.70 & 93.00 & 61.86 \\
Besto Humic + Chitosan & $39.90 \mathrm{~cd}$ & $39.90 \mathrm{bc}$ & 3.30 & 66.00 & 61.38 \\
Nemakey + Besto Humic + Chitosan & $23.76 \mathrm{~d}$ & $23.76 \mathrm{c}$ & 3.10 & 77.50 & 77.00 \\
Rugby® 100 ME (Control 1) & $69.46 \mathrm{~b}$ & $69.46 \mathrm{ab}$ & 4.10 & 82.00 & 32.77 \\
Water (Control 2) & $103.33 \mathrm{a}$ & $103.33 \mathrm{a}$ & 4.50 & 90.00 & - \\
LSD (P $\leq$ 0.05) & 25.83 & 35.58 & & & - \\
\hline
\end{tabular}

Data are means of three replicates. Data followed by the same letter in each column are not significantly different according to (LSD) test

Disease severity as shown in Table 7 appeared that lowest disease severity percentage was recorded by (Humic acid and Chitosan) which achieved higher significant $(\mathrm{p} \leq 0.05)$ effect followed by Chitosan and (Nemakey, Humic acid and Chitosan) compared to controls. 


\section{Plant growth characters}

\section{Vegetative system}

The combination treatments Nemakey, Humic acid and Chitosan significantly $(\mathrm{P} \leq 0.05)$ affected against $\mathrm{RKN}(M$. incognita and $M$. javanica) infection as compared to controls treatment. The reduction in growth parameters was indirectly proportional with the number of root-galls, so all screened treatments obviously improved plant growth parameters with various degrees (Table 8). Among tested treatments, plant receiving combined treatments (Nemakey, Humic acid and Chitosan) improved significantly in plant height and stem diameter with percentage of the dry weight of the vegetable parts amounted to $2.97 \mathrm{~cm}, 8.46 \mathrm{~cm}$ and $11.67 \%$ respectively which exceeded all other treatments as compared to control $2(1.61 \mathrm{~cm}, 6.17 \mathrm{~cm}$, and $28.07 \%)$. On the other hand, it was also observed that there were significant differences among the treatments $(\mathrm{p} \leq 0.05)$ with control 2, while with Rugby ${ }^{\circledR} 100$ ME (Conventional chemical control) or (Reference treatment), they were relatively had least effect. However, there were no significant differences among the treatments (with themselves).

Table 8. Effect of different treatments for controlling root-knot nematode (Meloidogyne spp.) on some plant growth parameters (vegetative parts) of cucumber (cv. Naseem F1)

\begin{tabular}{|c|c|c|c|c|c|c|c|}
\hline Treatment sets & $\begin{array}{c}\text { Plant } \\
\text { height } \\
(\mathrm{cm})\end{array}$ & $\begin{array}{c}\text { Stem } \\
\text { diameter } \\
(\mathbf{c m})\end{array}$ & $\begin{array}{l}\text { No. of } \\
\text { nodes. } \\
\text { plant }^{-1}\end{array}$ & $\begin{array}{l}\text { No. of } \\
\text { leaves. } \\
\text { plant }^{-1}\end{array}$ & $\begin{array}{c}\text { Fresh plant } \\
\text { weight } \\
\text { (vegetable } \\
\text { parts) g }^{\text {pant }}{ }^{-1} \\
\end{array}$ & $\begin{array}{c}\text { Leaf area. } \\
\text { plant }^{-1} \\
\left(\mathrm{~cm}^{2}\right)\end{array}$ & $\begin{array}{c}\% \text { of the } \\
\text { dry weight } \\
\text { of the } \\
\text { vegetative } \\
\text { parts } \\
\end{array}$ \\
\hline Nemakey & $2.40 \mathrm{bc}$ & $7.68 \mathrm{bc}$ & $40.66 \mathrm{de}$ & $26.66 \mathrm{~b}$ & 293.30 cde & $250.68 \mathrm{ab}$ & 20.87 \\
\hline Besto Humic (Humic acid) & $2.38 \mathrm{c}$ & $7.86 \mathrm{~b}$ & $39.66 \mathrm{e}$ & $26.66 \mathrm{~b}$ & $271.66 \mathrm{de}$ & $241.13 \mathrm{abc}$ & 20.91 \\
\hline Chitosan & $2.35 \mathrm{c}$ & $7.14 \mathrm{c}$ & $39.33 \mathrm{e}$ & $26.66 \mathrm{~b}$ & $274.90 \mathrm{de}$ & $215.07 \mathrm{~cd}$ & 16.10 \\
\hline Nemakey + Besto Humic (Humic acid) & $2.63 \mathrm{~b}$ & $7.84 \mathrm{~b}$ & $48.66 \mathrm{~b}$ & $40.00 \mathrm{a}$ & $424.90 \mathrm{ab}$ & $261.52 \mathrm{ab}$ & 13.96 \\
\hline Nemakey + Chitosan & $2.46 \mathrm{bc}$ & $7.67 \mathrm{bc}$ & $42.66 \mathrm{~cd}$ & $40.00 \mathrm{a}$ & $339.43 \mathrm{bcd}$ & $231.68 \mathrm{bcd}$ & 17.03 \\
\hline Besto Humic (Humic acid) + Chitosan & $2.52 \mathrm{bc}$ & $7.76 \mathrm{~b}$ & $44.66 \mathrm{c}$ & $39.66 \mathrm{a}$ & $386.33 \mathrm{abc}$ & $239.30 \mathrm{abc}$ & 14.67 \\
\hline Nemakey + Besto Humic (Humic acid) + Chitosan & $2.97 \mathrm{a}$ & $8.46 \mathrm{a}$ & $50.33 \mathrm{ab}$ & $42.33 \mathrm{a}$ & $480.20 \mathrm{a}$ & $266.99 \mathrm{a}$ & 11.67 \\
\hline Rugby $® 100$ ME (Control 1) & $2.07 \mathrm{~d}$ & $7.47 \mathrm{bc}$ & $34.33 \mathrm{f}$ & $26.66 \mathrm{~b}$ & $229.96 \mathrm{e}$ & $231.12 \mathrm{bcd}$ & 24.05 \\
\hline Water (Control 2) & $1.61 \mathrm{e}$ & $6.17 \mathrm{~d}$ & $27.66 \mathrm{~g}$ & $21.00 \mathrm{~b}$ & $201.30 \mathrm{e}$ & $196.63 \mathrm{~d}$ & 28.07 \\
\hline $\operatorname{LSD}(\mathrm{P} \leq 0.05)$ & $0.24 \mathrm{u}$ & $0.56 \mathrm{u}$ & $2.17 \mathrm{u}$ & $7.91 \mathrm{u}$ & $96.75 \mathrm{u}$ & $35.09 \mathrm{u}$ & - \\
\hline
\end{tabular}

Data are means of three replicates. Data followed by the same letter in each column are not significantly different according to (LSD) test

Results in Table 8 show that other parameters of cucumber plant growth i.e. no. of nodes/plant and plant weight (vegetative parts) / plant (g) were significantly affected by applying these combined treatments (Nemakey, Humic acid and Chitosan) and (Nemakey and Humic acid) when compared to controls. On the other hand, there was less effect of the treatments on the no. of leaves. plant ${ }^{-1}$ if compared to the controls $(1+2)$.

\section{Root system}

There was a significant $(\mathrm{P} \leq 0.05)$ difference between the root length $(\mathrm{cm})$, fresh root weight $(\mathrm{g})$ and dried root weight $(\mathrm{g})$ of the cucumber plants treated with different treatments of Nemakey, Humic acid, Chitosan and controls as shown in Table 9.

All the treatments were significantly $(\mathrm{P} \leq 0.05)$ different on the basis of root length. Maximum root length $(32.08,31.74$ and $31.70 \mathrm{~cm})$ was recorded in the plants treated with combined (Nemakey, Humic acid and Chitosan), (Nemakey and Humic acid) and 
(Nemakey and Chitosan) respectively, as compared to controls. Minimum root length $(25.38 \mathrm{~cm})$ was recorded in untreated control plants (control 2). It can also be noticed that (Nemakey + Humic acid and Chitosan), (Humic acid and Chitosan) and (Nemakey and Humic acid) were significantly showed reasonable improved fresh root weight and ranked the most active one among the other treatments for increasing fresh root weight of cucumber plant with $34.86,30.60$ and $30.76 \mathrm{~g}$, respectively as compared to control 2, which was recorded $24.46 \mathrm{~g}$. In the meanwhile, plants receiving combined treatments (Nemakey, Humic acid and Chitosan) and (Humic acid and Chitosan) gave significantly better dried root weight than all other treatments, followed by (Nemakey and, Humic acid) as compared to control.

Table 9. Effect of different treatments for controlling root-knot nematode (Meloidogyne spp.) on some plant growth (root parts) of cucumber (cv. Naseem F1)

\begin{tabular}{c|c|c|c}
\hline Treatment sets & $\begin{array}{c}\text { Root length } \\
(\mathbf{c m})\end{array}$ & $\begin{array}{c}\text { Fresh root } \\
\text { weight }(\mathbf{g})\end{array}$ & $\begin{array}{c}\text { Dried root } \\
\text { weight }(\mathbf{g})\end{array}$ \\
\hline Nemakey & $30.24 \mathrm{abc}$ & $29.13 \mathrm{~b}$ & $11.31 \mathrm{~d}$ \\
Besto Humic (Humic acid) & $29.86 \mathrm{abc}$ & $29.03 \mathrm{~b}$ & $12.91 \mathrm{~cd}$ \\
Chitosan & $27.19 \mathrm{bcd}$ & $28.70 \mathrm{bc}$ & $11.76 \mathrm{~d}$ \\
Nemakey + Besto Humic (Humic acid) & $31.74 \mathrm{a}$ & $30.76 \mathrm{ab}$ & $14.23 \mathrm{bc}$ \\
Nemakey + Chitosan & $31.70 \mathrm{a}$ & $29.43 \mathrm{~b}$ & $11.81 \mathrm{~d}$ \\
Besto Humic (Humic acid) + Chitosan & $31.58 \mathrm{ab}$ & $30.60 \mathrm{ab}$ & $15.07 \mathrm{ab}$ \\
Nemakey + Besto Humic (Humic acid) + Chitosan & $32.08 \mathrm{a}$ & $34.86 \mathrm{a}$ & $16.46 \mathrm{a}$ \\
Rugby® 100 ME (Conventional chemical control) (Control 1) & $27.10 \mathrm{~cd}$ & $27.50 \mathrm{bc}$ & $8.22 \mathrm{e}$ \\
Water (Control 2) & $25.38 \mathrm{~d}$ & $24.46 \mathrm{c}$ & $6.06 \mathrm{f}$ \\
LSD (P $\leq$ 0.05) & 4.42 & 4.29 & 1.72 \\
\hline
\end{tabular}

Data are means of three replicates. Data followed by the same letter in each column are not significantly different according to (LSD) test

\section{Leaf chlorophyll and NPK content}

Data as shown in Table 10 summarize the description of the leaf chlorophyll intensity, the percentage of the Nitrogen $(\mathrm{N})$, Phosphor $(\mathrm{P})$ and potassium $(\mathrm{K})$ content in the cucumber leaves as influenced by $M$. incognita and $M$. javanica infection and effect of applying Nemakey, Humic acid and Chitosan whether alone or in combination in comparison to Rugby ${ }^{\circledR} 100 \mathrm{ME}$ (Conventional chemical control) (Reference treatment) or (control 1) and spray water only (control 2) in the greenhouse conditions.

Obviously, results in Table 11 show that two of them significantly $(\mathrm{P} \leq 0.05)$ achieved high percentage increase the values of the leaf chlorophyll intensity and percentage of the Nitrogen $(\mathrm{N})$ content in the leaf per $(1 \mathrm{~g})$ of dry weight under study. Among tested treatments, the combined treatments (Nemakey, Humic acid and Chitosan), (Nemakey and Humic acid) and (Humic acid and Chitosan) were superior in values of leaf chlorophyll $(38.19,35.35$ and 35.10$)$ respectively as compared to controls (28.77 and 24.79), whereas the combined treatments (Nemakey, Humic acid and Chitosan) and (Nemakey and Humic acid) ranked the first increase in percentage values of Nitrogen $(\mathrm{N})$ content in the leaf per $(1 \mathrm{~g})$ of dry weight which were 4.86 and $4.83 \%$ respectively as compared to control $2(4.56 \%)$. In addition, it is appeared that there were no significant differences among the treatments and controls on percentage of the 
Phosphor $(\mathrm{P})$ and Potassium $(\mathrm{K})$ content in the leaves (Table 8), and chlorosis of the leaves (pale green tended to yellowing).

Table 10. Effect of different treatments for controlling root-knot nematode (Meloidogyne spp.) on some plant content of cucumber (cv. Naseem F1)

\begin{tabular}{c|c|c|c|c}
\hline Treatment sets & $\begin{array}{c}\text { Leaf chlorophyll } \\
\text { intensity (SPAD } \\
\text { unit) }\end{array}$ & $\begin{array}{c}\text { \% of the nitrogen } \\
\text { (N) content in the } \\
\text { leaf dry weight }\end{array}$ & $\begin{array}{c}\text { \% of the } \\
\text { phosphor (P) } \\
\text { content in the } \\
\text { leaf dry weight }\end{array}$ & $\begin{array}{c}\text { \% of the } \\
\text { potassium (K) } \\
\text { content in the } \\
\text { leaf dry weight }\end{array}$ \\
\hline Nemakey & $31.58 \mathrm{~cd}$ & $4.66 \mathrm{abc}$ & $0.36 \mathrm{a}$ & $3.08 \mathrm{a}$ \\
Besto Humic (Humic acid) & $31.54 \mathrm{~cd}$ & $4.60 \mathrm{bcd}$ & $0.35 \mathrm{a}$ & $3.23 \mathrm{a}$ \\
Chitosan & $31.50 \mathrm{~cd}$ & $4.40 \mathrm{~d}$ & $0.32 \mathrm{a}$ & $3.22 \mathrm{a}$ \\
Nemakey + Besto Humic (Humic acid) & $35.35 \mathrm{ab}$ & $4.83 \mathrm{ab}$ & $0.31 \mathrm{a}$ & $3.43 \mathrm{a}$ \\
Nemakey + Chitosan & $33.64 \mathrm{bc}$ & $4.66 \mathrm{abc}$ & $0.36 \mathrm{a}$ & $3.46 \mathrm{a}$ \\
Besto Humic (Humic acid) + Chitosan & $35.10 \mathrm{ab}$ & $4.70 \mathrm{abc}$ & $0.35 \mathrm{a}$ & $3.22 \mathrm{a}$ \\
Nemakey + Besto Humic (Humic acid) + Chitosan & $38.19 \mathrm{a}$ & $4.86 \mathrm{a}$ & $0.36 \mathrm{a}$ & $3.23 \mathrm{a}$ \\
Rugby® 100 ME (Control 1) & $28.77 \mathrm{~d}$ & $4.73 \mathrm{abc}$ & $0.35 \mathrm{a}$ & $3.24 \mathrm{a}$ \\
Water (Control 2) & $24.79 \mathrm{e}$ & $4.56 \mathrm{~cd}$ & $0.32 \mathrm{a}$ & $3.14 \mathrm{a}$ \\
LSD (P $\leq$ 0.05) & $3.33 \mathrm{u}$ & $0.25 \mathrm{u}$ & $0.07 \mathrm{u}$ & $0.51 \mathrm{u}$ \\
\hline
\end{tabular}

Data are means of three replicates. Data followed by the same letter in each column are not significantly different according to (LSD) test

Table 11. Effect of different treatments for controlling root-knot nematode (Meloidogyne spp.) of cucumber (cv. Naseem F1) on floral growth

\begin{tabular}{|c|c|c|c|c|c|c|c|c|}
\hline Treatment sets & $\begin{array}{c}\text { No. of } \\
\text { flowers. } \\
\text { plant }^{-1}\end{array}$ & $\begin{array}{c}\text { No. of } \\
\text { aborted } \\
\text { flowers. } \\
\text { plant }^{-1}\end{array}$ & $\begin{array}{l}\text { No. of } \\
\text { fruit. }^{-1} \\
\text { plant }^{-1}\end{array}$ & $\begin{array}{c}\text { Fresh } \\
\text { weight of } \\
\text { fruit. } \\
\text { plant }^{-1}(\mathrm{~g})\end{array}$ & $\begin{array}{c}\text { Diameter } \\
\text { of fruits } \\
\text { (cm) }\end{array}$ & $\begin{array}{c}\text { Length of } \\
\text { fruits } \\
(\mathrm{cm})\end{array}$ & $\begin{array}{c}\text { Fruit } \\
\text { moisture } \\
\text { content } \\
(\%)\end{array}$ & $\begin{array}{c}\text { Vegetative/ } \\
\text { fruit ratio } \\
\text { (W/W) }\end{array}$ \\
\hline Nemakey & $41.00 \mathrm{~cd}$ & $48.93 \mathrm{ab}$ & $33.00 \mathrm{~cd}$ & $85.76 \mathrm{ab}$ & $2.77 \mathrm{a}$ & $13.70 \mathrm{ab}$ & $97.59 \mathrm{a}$ & 29.91 \\
\hline Besto Humic (Humic acid) & $44.00 \mathrm{ab}$ & $50.50 \mathrm{a}$ & $34.66 \mathrm{bcd}$ & $86.70 \mathrm{ab}$ & $2.79 \mathrm{a}$ & $13.27 \mathrm{bc}$ & $97.52 \mathrm{a}$ & 32.44 \\
\hline Chitosan & $41.00 \mathrm{~cd}$ & $47.66 \mathrm{ab}$ & $31.66 \mathrm{~d}$ & $84.75 \mathrm{ab}$ & $2.68 \mathrm{a}$ & $13.12 \mathrm{bc}$ & $97.63 \mathrm{a}$ & 32.05 \\
\hline Nemakey + Besto Humic (Humic acid) & $44.66 \mathrm{a}$ & $46.06 \mathrm{ab}$ & $36.66 \mathrm{ab}$ & $92.05 \mathrm{a}$ & $2.78 \mathrm{a}$ & $14.31 \mathrm{a}$ & $97.41 \mathrm{a}$ & 21.71 \\
\hline Nemakey + Chitosan & $43.00 \mathrm{abc}$ & $44.80 \mathrm{ab}$ & $36.33 \mathrm{abc}$ & $88.81 \mathrm{ab}$ & $2.69 \mathrm{a}$ & $13.39 \mathrm{~b}$ & $97.69 \mathrm{a}$ & 27.91 \\
\hline Besto Humic (Humic acid) + Chitosan & $42.00 \mathrm{bcd}$ & $46.13 \mathrm{ab}$ & $36.66 \mathrm{ab}$ & $89.27 \mathrm{ab}$ & $2.76 \mathrm{a}$ & $13.51 \mathrm{ab}$ & $97.66 \mathrm{a}$ & 23.20 \\
\hline $\begin{array}{c}\text { Nemakey }+ \text { Besto Humic (Humic acid) }+ \\
\text { Chitosan }\end{array}$ & $43.66 \mathrm{ab}$ & $42.96 \mathrm{~b}$ & $38.66 \mathrm{a}$ & $92.70 \mathrm{a}$ & $2.75 \mathrm{a}$ & $14.30 \mathrm{a}$ & $97.47 \mathrm{a}$ & 19.36 \\
\hline Rugby $® 100$ ME (Control 1) & $39.66 \mathrm{de}$ & $51.23 \mathrm{a}$ & $27.00 \mathrm{e}$ & $84.77 \mathrm{ab}$ & $2.66 \mathrm{a}$ & $13.52 \mathrm{ab}$ & $97.49 \mathrm{a}$ & 36.51 \\
\hline Water (Control 2) & $38.00 \mathrm{e}$ & $51.00 \mathrm{a}$ & $24.00 \mathrm{e}$ & $80.74 \mathrm{~b}$ & $1.70 \mathrm{~b}$ & $12.50 \mathrm{c}$ & $96.15 \mathrm{~b}$ & 44.08 \\
\hline $\operatorname{LSD}(\mathrm{P} \leq 0.05)$ & $2.49 \mathrm{u}$ & $7.21 \mathrm{u}$ & $3.53 \mathrm{u}$ & $10.67 \mathrm{u}$ & $0.14 \mathrm{u}$ & $0.85 \mathrm{u}$ & $0.64 \mathrm{u}$ & - \\
\hline
\end{tabular}

Data are means of three replicates. Data followed by the same letter in each column are not significantly different according to (LSD) test

\section{Plant yield parameters}

\section{Floral growth}

Data in Table 9 elicit the impact of Nemakey, Humic acid and Chitosan in comparison with Rugby ${ }^{\circledR} 100 \mathrm{ME}$ (Conventional chemical control)(control 1) and water spray (control 2) on RKN, M. incognita and $M$. javanica infection and the consequent effect on plant yield parameters of cucumber plant under plastic house conditions. The highest and significant $(\mathrm{P} \leq 0.05)$ number of flowers per plant was recorded (44.66) when plant received the combined treatments (Nemakey and Humic acid) as compared to controls (39.66 and 38.00) respectively. Meanwhile, combined 
treatments (Nemakey, Humic acid and Chitosan) significantly were the highest effective on reduction number of aborted flowers per plant and increasing number of fruit. plant ${ }^{-1}$ which recorded (42.96 and 38.66) respectively as compared to controls. In addition, the fresh weight of fruit $(\mathrm{g})$ per plant and length of fruits $(\mathrm{cm})$ in $($ Nemakey and Humic acid) and (Nemakey, Humic acid, Chitosan) combined treatments recorded significantly higher than those recorded in the other treatments as compared to controls. Whereas no significant differences were found in diameter of fruits $(\mathrm{cm})$ and percentage of fruit moisture content among the treatments with themselves but at the same time there were significant effects among those treatments in comparison to control 2. In addition, the vegetative / Fruit ratio (W/W) was influenced by treatment with (Nemakey, Humic acid and Chitosan) that produced significantly result with least value than the other treatments and recorded (19.36), followed by (Nemakey, Humic acid) and (Humic acid and Chitosan) were (21.71 and 23.20) respectively as compared to control 1.

\section{Yield growth}

Table 12 shows the effect of each of Nemakey, Humic acid and Chitosan alone or in combination on early yield, total yield and percentage of yield increasing of cucumber plant which influence by infection of RKN $M$. incognita and $M$. javanica under plastic house condition. In spite of no significant differences were found among treatments with controls in early yield, but among the three combined treatments, one of them recorded the highest value as compared to controls. Meanwhile, the higher and significant marketable total yields and percentage of yield increasing obtained in combination treatments (Nemakey, Humic acid and Chitosan) and (Nemakey, Humic acid) which recorded (6.36 and 6.29\%) and (167.22 and 164.28\%), respectively as compared to controls (4.19 and $2.38 \%)$.

Table 12. Effect of different treatments for controlling root-knot nematode (Meloidogyne spp.) of cucumber (cv. Naseem F1) on yield

\begin{tabular}{c|c|c|c}
\hline Treatment sets & $\begin{array}{c}\text { Early yield } \\
\text { (kg. plant }^{-1} \text { ) }\end{array}$ & $\begin{array}{c}\text { Total yield } \\
\text { (kg. plant }^{-1} \text { ) }\end{array}$ & \% of yield increasing \\
\hline Nemakey & $0.70 \mathrm{ab}$ & $4.76 \mathrm{bc}$ & 100.00 \\
Besto Humic (Humic acid) & $0.72 \mathrm{ab}$ & $4.87 \mathrm{abc}$ & 104.62 \\
Chitosan & $0.87 \mathrm{ab}$ & $4.48 \mathrm{c}$ & 88.23 \\
Nemakey + Besto Humic (Humic acid) & $1.00 \mathrm{ab}$ & $6.29 \mathrm{ab}$ & 164.28 \\
Nemakey + Chitosan & $0.99 \mathrm{ab}$ & $4.96 \mathrm{abc}$ & 108.40 \\
Besto Humic (Humic acid) + Chitosan & $1.09 \mathrm{ab}$ & $5.38 \mathrm{abc}$ & 126.05 \\
Nemakey + Besto Humic (Humic acid) + Chitosan & $1.27 \mathrm{a}$ & $6.36 \mathrm{a}$ & 167.22 \\
Rugby® 100 ME (Control 1) & $0.89 \mathrm{ab}$ & $4.19 \mathrm{c}$ & 76.05 \\
Water (Control 2) & $0.42 \mathrm{~b}$ & $2.38 \mathrm{~d}$ & - \\
LSD (P $\leq 0.05)$ & $0.79 \mathrm{u}$ & $1.52 \mathrm{u}$ & - \\
\hline
\end{tabular}

Data are means of three replicates. Data followed by the same letter in each column are not significantly different according to (LSD) test

\section{Discussion}

Depending on the morphological characteristic (perineal patterns), it has been revealed that there were two species of root-knot nematodes, described and recorded as Meloidogyne incognita and M. javanica (Whitehead, 1968; Esser et al., 1976). The two species usually accompanied with many vegetable and non-vegetable plant, previous 
studies showed the same results (Taylor and Sasser, 1978; Moens et al., 2009). On the other hand, these two species were found in a mixed population as mentioned by (Marahatta et al., 2012; Kayani et al., 2013). when explained perineal pattern of $M$. incognita. Whereas, the perineal patterns for $M$. javanica was typical with a rounded to flattened dorsal arch and conspicuous lateral lines that clearly separated the dorsal and ventral regions of the patterns (Fig. 2A, B). Same notation observed by Eisenback et al. (1985), Sen and Chatterjee (2007), Bohra (2011) For confirmation of the diagnosing and identification of the nematodes molecular markers have been used, by applying specific- species primers. The concentration and purity of DNA extraction for $25 \mathrm{mg}$ of $\mathrm{J} 2 \mathrm{~s}$, males and females of $M$. incognita and $M$. javanica were $69.4 \mathrm{ng} / \mu \mathrm{L}$ and 2.52 purity respectively when measured by using NanoDrop 2000C device. Different programs and annealing temperature were followed to amplify the specific DNA position of both species (Meloidogyne incognita and Meloidogyne javanica. The procedure of DNA amplification has been performed six times and all pair primers were set up according to the annealing temperature for first and second times that mentioned by the manufacture company (Sinacion, Bioscience Co. Iran). Our result was agreed with the outcome of other researchers) according to Zijlstra et al. (2000), Dong et al. (2001), Devran et al. (2009), Mwesige (2013), Toumi et al. (2014), Chanmalee (2014), Zhuran et al. (2014), Temple et al. (2015), Kemei et al. (2015), Ye et al. (2015), Agenbag (2016) and Aydinli and Mennan (2016) who used these species-specific primers for diagnosing both species of Meloidogyne by molecular characteristics.

In the plastic house experiment, different treatments have been used in order to investigate their influence on controlling the population densities and numbers of juveniles 2 before applying the treatments and after 10, 20 and 30 days. The present results show an approach to control $M$. incognita and $M$. javanica in cucumber plant using modern methods and more active for controlling Meloidogyne which are safer than nematicides. These results should be considered during designing an integrated pest management program for RKN or other nematode pathogens in cucumber and other crops.

The reduction of RKNs population in combination (Nemakey, humic acid and Chitosan) could be attributed to Nemakey extracts compounds (marigold, sesame, thyme, etc.), this extract contains Allelopathic compounds such as alpha-terthienyl which produced by plants as secondary metabolites that have significant effects on the activity of nematodes and were thought to be toxins and act as nematicidal action affected on reducing population densities. These finding completely agreed with the previous studies when they used these extracts in their researches (Visser and Vythftingam, 1959; Tsay et al., 2004; Ibrahim et al., 2006; Kong et al., 2007; Krueger et al., 2007; Elbadri and Yassin, 2010; Hooks et al., 2010). The effect of Nemakey was appeared after 30 days of application, this time agreed with the manufacturer product (Nemakey) who mentioned the effecting time of Nemakey is between 25-35 days. On the other hand, Humic acid also reduced nematode population due to improving the nutrient availability and impact on other important chemical, biological, and physical properties of soils, this conclusion in agreement with (Khaled and Fawy, 2011; Fahramand et al., 2014). It was also observed that the efficiency of Humic acid increased when it applied in combination, these outcomes were in comport with those investigation of (Saravanapriya and Subramanian, 2007; Gondal et al., 2014; El-Sherif et al., 2015). At the same time Chitosan also played its role during increasing cytosolic $\mathrm{Ca}^{2}$, activation of MAP-kinases, oxidative burst, callus apposition, increase in pathogen- 
related proteins (PRP), phenolic acid synthesis, phytoalexin accumulation, hypersensitive response (HR) proteinase inhibitors and lignin synthesis subsequently enhance the defense of the cucumber plant to RKN infections and decreasing nematode population densities (Hadwiger, 2013; Malerba and Cerana, 2016). Results revealed that reproduction factor (Rf) was adversely affected by treatments whether alone or in combination. Plants which received combined treatments (Nemakey, Humic acid and Chitosan) and (Nemakey and Chitosan) significantly $(\mathrm{p} \leq 0.05)$ dominated other treatments in reducing number of total nematode population (pf) as compared to controls. It is worthy to observe that Nemakey's compound as a nematicide ranked first in diminishing nematode final population with Humic acid and Chitosan which they have the important role for the decreasing nematode population in the soil as shown in Table 6 subsequently it has role of reducing the (Rf) value. This conclusion is approved by many previous studies when they used Humic acid or Chitosan whether alone or in a combination with other treatments (Elmiligy and Norton, 1973; Kesba and Al-Shalaby, 2008; Khalil and Badawy, 2012; Dina et al., 2013; El-Sayed and Mahdy, 2015; ElSherif et al., 2015; Mota and dos Santos, 2016).

As the organic fertilizer and nematicide, Nemakey has been newly manufactured by the Turkish Merkez Anadolu Kimya Sanayi Company. In fact, during reconsideration the references, it could not be found any researches in this field whether applied it alone or in combination to control RKN, so we could not compare our results with the results of previous studies, but depend on its compounds (marigold, sesame, thyme, organic acid oils, free natural amino acids) we could compare our results with the results of other researchers who they used these components in their researches.

All the treatments had significantly reduced the root galls, gall index, disease severity and percentage of gall decrease as compared to controls, a great variability was observed in nematode development and reproduction. Good efficacy of Nemakey, Humic acid and plant protector Chitosan found to be the most effective in reducing the root galls, gall index and disease severity and percentage of gall decreasing endorsing the plant growth parameters. Chitosan show good effect in reducing RKN due to developed systemic acquired resistance (SAR) in cucumber plants. This result agrees with Hadwiger (2013), Malerba and Cerana (2016) and Mota and dos Santos (2016). Nemakey affected on RKN due to its potential killing nematodes at all of its stages of life. Nemakey destroys nematode eggs and creates an unfriendly environment in the soil, which complicate reproduction and proliferation of plant parasitic nematodes in addition to its activity as a bio-stimulant product to promote the production of main and secondary roots (http://www. merkezanadolu.com.tr/nemakey-e0f), the present results in agreement with other studies (Husain et al.,1984; Swamy et al., 1995; Krueger et al., 2007; Abd-Elgawad and Omer, 1995; Ibrahim et al., 2006; Natarajan et al., 2006). Humic acid has role in reducing number of galls. The present results were in agreement with the findings that reported by Kesba and Al-Shalaby (2008) and Saravanapriya and Subramanian (2005). It was observed that the chemical nematicide Rugby® $100 \mathrm{ME}$ had lower effect on reducing number of galls, this outcome came to an agreement with another study (Safdar et al., 2013).

In the present study, effect of the essential oils and extract Nemakey's compounds which are mixture of different compound made more than one mechanism of action exist. Some of the recently proposed hypotheses concerning mechanisms of action of essential oils include denaturation of proteins, inhibition of enzyme action, and interference with electron flow in the respiratory chain, or with ADP phosphorylation 
(Abd-Elgawad and Omer, 1995). On the other hand, Humic acid has been reported to improve root development and plant growth (Adani et al., 1998). This finding is in agreement with earlier observations made by many scientists who confirmed that Nemakey's compound enhanced the growth parameters of tomato plant (Natarajan et al., 2006).

Using Humic acid through soil might be more helpful in enhancing the plant growth under RKN infection (Gondal et al., 2014), so applied Humic acid stimulation cucumber plant growth parameters through increasing cell division, as well as optimizing uptake of nutrients and water (El-Sherif et al., 2015) as compared to controls due to their effect on the reducing by its influences on the nematode infecundity (nematode population) subsequently decreasing the root galls as compared to controls.

The present results were in agreement with the findings that reported by Kesba and El-Beltagi (2012) in grape rootstocks, Gondal et al. (2014) in potato plant and Dina et al. (2013) improved plant growth parameters of sugar-beet against nematode infection. On the other hand Chitosan was very effective against the RKN under plastic house conditions (Malerba and Cerana, 2016) so it has been used in this experiment as a powerful elicitor than a direct antimicrobial or toxic agent, therefore it had important role to increase plant parameter due to promote elicitation and signaling to systemic acquired resistance (SAR) subsequently protective mechanisms activation in plant tissues inhibited the growth of RKN (Dörnenburg and Knorr, 1997; Heil, 1999; Neto et al., 2005; Strange, 2006; Choudhary et al., 2007; Badawy and Rabea, 2011; Zargar et al., 2015), these results in agreement with the results of others researcher who used chitosan in their studies (Zinov'eva et al., 1999; Kloepper et al., 2004; Khalil and Badawy, 2012; El-Sayed and Mahdy, 2015).

There was a correlation between root growth parameters and nematode infestations, Kankam and Adomako (2014) also pointed to the same fact. The present study showed that Nemakey compounds, Humic acid and Chitosan compounds enhanced the cucumber root growth to a different extent over the controls. This finding is in agreement with earlier observations made by many scientists who confirmed that Nemakey's compound, Humic acid and Chitosan in a combination stimulated the development of the growth in root system (Radwan et al., 2012); Dina et al., 2013; Gondal, et al., 2014; Khalil and Badawy, 2012; El-Sayed and Mahdy, 2015).

It is appeared that there were no significant differences among the treatments and controls on percentage of the Phosphor $(\mathrm{P})$ and Potassium $(\mathrm{K})$ content in the leaves, chlorosis (pale green tended to yellowing) this result also mentioned by Olsen (2011), Karssen and Moens (2006) and Mitkowski and Abawi (2003). In fact, leaves chlorosis not only caused by the low availability of mineral nutrient in soil but also to the impaired translocation of nutrients in plants infested by RKN that is able to damage and to block the vascular system of host plants similar results were obtained by Ogaraku (2007) on cowpea plants, therefore leaf chlorophyll intensity in cucumber plants was influenced by the higher and lower level of RKN as reported by Amin and Abd ElWanis (2014). The leaf chlorophyll and Nitrogen (N) content have the important role for increasing process of photosynthesis and increasing crop yield, the present results were in agreement with the findings that reported by Hao and Papadopoulos (1999) and Yang et al. (2009) who recorded the same result in cucumber plant.

A positive correlation has noticed between treatments and cucumber floral parameters, therefore all screened treatments whether alone or in combination obviously improved plant floral growth due to effect on inhibition nematodes population directly 
or indirectly (Tables 8 and 9) and improved crop yield quality and quantity during increasing vegetative growth of cucumber, subsequently increasing number of flowers and decreasing number of aborted flowers per plant, this finding is in agreement with Polthanee and Yamazaki (1996), Elbadri and Yassin (2010), Arncon et al. (2006), Shafeek et al. (2016) and Malerba and Cerana (2016).

The early and total yield reductions were often directly related to the RKN levels in the soil table (4.2) and the environmental stresses imposed upon the plant during crop growth. In general, the more presence of root-knot suggests a potentially serious problem, so at very high levels the RKN significantly affect plant health especially the roots function; stabilization of the plant, ability of the absorption and root secretions (the healthy plant root usually secrets various compounds involved phenolic compounds, complex saguaros, simple saguaros and growth hormones) therefore it indirectly influence on significantly marketable yield as reported also by Noling (1999). So, treating cucumber plant with Nemakey, Humic acid and Chitosan improve total yield and percentage of yield increasing, as mentioned by many researchers in their studies (Arancon et al., 2006 on pepper plant; Saravanapriya and Subramanian, 2007; Amin and Abd El-Wanis, 2014; Shafeek et al., 2016.

\section{Conclusion}

It is concluded from the results that based on the morphological and molecular characteristics in the current study, two species of Meloidogyne RKN were diagnosed as; Meloidogyne incognita (Kofoid \& White) Chitwood, and M. javanica (Treub) Chitwood which are common in green or plastic houses at Bakrajo district. The combination of treatments (Nemakey, Humic acid and Chitosan) gave the best results in the majority of studied parameters followed by (Nemakey and Humic acid) and (Humic acid, Chitosan) which gave better results after the three combined treatment for controlling RKN. From this study revealed that these improved the health of cucumber plants and increased the nitrogen content in the leaves (Tables 3 and 10). More studies need to be conducted to obtain detail surveying and investigation about other species which might be accompanied with vegetable crops especially cucumber. We recommend using other methods like biological control as a complementary of integrated disease management (IDM). It was recommended studying some botanical nematicide like garlic, rosemary and mints.

\section{REFERENCES}

[1] Abawi, G. S., Widmer, T. L. (2000): Impact of soil health management practices on soilborne pathogens, nematodes and root diseases of vegetable crops. - Applied Soil Ecology 15: 37-47.

[2] Abd-Elgawad, M. M., Omer, E. A. (1995): Effect of essential oils of some medicinal plants on phytonematodes. - Anzeiger für Schädlingskunde, Pflanzenschutz, Umweltschutz 68: 82-84.

[3] Adam, M., Phillips, M., Blok, V. (2007): Molecular diagnostic key for identification of single juveniles of seven common and economically important species of root-knot nematode (Meloidogyne Spp.). - Plant Pathology 56: 190-197.

[4] Adani, F., Genevini, P., Zaccheo, P., Zocchi, G. (1998): The effect of commercial humic acid on tomato plant growth and mineral nutrition. - Journal of Plant Nutrition 21: 561-575. 
[5] Agenbag, M. (2016): Identification and reproduction potential of South African Meloidogyne species. - Magister Scientiae, Environmental Sciences, Potchefstroom Campus of the North-West University.

[6] Agrios, G. N. (2005): Plant Pathology. Fifth Ed. - Elsevier Academic Press, New York.

[7] Amin, A. W., Abd El-Wanis, M. (2014): Protecting cucumber against root-knot nematode, Meloidogyne Incognita using grafting onto resistant cucurbit rootstocks and interplanted Tagetes Spp. as an alternative to Cadusafos nematicide under protected plastic house conditions. - Middle East Journal of Agriculture Research 3: 167-175.

[8] Arancon, N. Q., Edwards, C. A., Lee, S., Byrne, R. (2006): Effects of humic acids from vermicomposts on plant growth. - European Journal of Soil Biology 42: 65-69.

[9] Atamian, H. S., Roberts, P. A., Kaloshian, I. (2012): High and low throughput screens with root-knot nematodes Meloidogyne spp.- Journal of Visualized Experiments 61: 1-5.

[10] Aydinli, G., Mennan, S. (2016): Identification of root-knot nematodes (Meloidogyne spp.) from greenhouses in the Middle Black Sea region of Turkey. - Turkish Journal of Zoology 40: 675-685.

[11] Badawy, M. E. I., Rabea, E. I. (2011): A biopolymer chitosan and its derivatives as promising antimicrobial agents against plant pathogens and their applications in crop protection. - International Journal of Carbohydrate Chemistry 2011(Special issue): 1-29.

[12] Bird, D. M., Opperman, C. H., Williamson, V. M. (2008): Plant Infection by Root-Knot Nematode. - In: Berg, R. H., Taylor, C. G. (eds.) Cell Biology of Plant Nematode Parasitism. Plant Cell Monographs. Springer Science \& Business Media, Berlin Heidelberg, pp. 1-13.

[13] Bohra, P. (2011): Pictorial Handbook on Plant and Soil Nematodes of Rajasthan. Zoological Survey of India, Kolkata.

[14] Bonuke, N. S. (2013): Incidence, prevalence and management of root-knot nematodes (Meloidogyne spp.) on selected indigenous leafy vegetables in Kisii and Trans-Mara Counties, Kenya. - Master of Science, Plant Pathology, Kenyatta University, Kenya.

[15] Castagnone-Sereno, P. (2002): Genetic variability in parthenogenetic root-knot nematodes, Meloidogyne spp., and their ability to overcome plant resistance genes. - Nematology 4: 605-608.

[16] Chanmalee, T. (2014): Variation of root-knot nematode infecting chili in Thailand. Master of Science, Agricultural Biotechnology, Kasetsart University, Thailand.

[17] Chapuis-Lardy, L., Diakhaté, S., Djigal, D., Ba, A. O., Dick, R. P., Sembéne, P. M., Masse, D. (2015): Potential of Sahelian native shrub materials to suppress the spiral nematode Helicotylenchus dihystera. - Journal of Nematology 47: 214-217.

[18] Choudhary, D. K., Prakash, A., Johri, B. N. (2007): Induced systemic resistance (ISR) in plants: mechanism of action. - Indian Journal of Microbiology 47: 289-297.

[19] Coste, S., Baraloto, C., Leroy, C., Marcon, É., Renaud, A., Richardson, A. D., Roggy, J.-C., Schimann, H., Uddling, J., Hérault, B. (2010): Assessing foliar chlorophyll contents with the SPAD-502 Chlorophyll meter: a calibration test with thirteen tree species of tropical rainforest in French Guiana. - Annals of Forest Science 67: 607-607.

[20] Crotty, F., Adl, S. M., Clegg, C. D., Blackshaw, R. P., Murray, P. J. (2009): Investigating soil food webs - tracking the translocation of C-13 and N-15 through microbial interactions within the soil. - Journal of Nematology 41: 321-322.

[21] Devran, Z., Söğüt, M. A. (2009): Distribution and identification of root-knot nematodes from Turkey. - Journal of Nematology 41: 128-133.

[22] Dina, S. S. I., Nour El-Deen, A. H., Khalil, A. E., Fatma, A. M. M (2013): Induction of systemic resistance in sugar-beet infected with Meloidogyne incognita by humic acid, hydrogen peroxide, thiamine and two amino acids. - Egypt J. Agro-nematol 12: 22-41.

[23] Dong, K., Dean, R. A., Fortnum, B. A., Lewis, S. A. (2001): Development of PCR primers to identify species of root-knot nematodes: Meloidogyne arenaria, M. hapla, M. incognita and M. javanica. - Nematropica 31: 271-280. 
[24] Dong, L., Huang, C., Huang, L., Li, X., Zuo, Y. (2012): Screening plants resistant against Meloidogyne incognita and integrated management of plant resources for nematode control. - Crop Protection 33: 34-39.

[25] Dörnenburg, H., Knorr, D. (1997): Evaluation of elicitor-and high-pressure-induced enzymatic browning utilizing potato (Solanum tuberosum) suspension cultures as a model system for plant tissues. - Journal of Agricultural and Food Chemistry 45: 4173-4177.

[26] Eisenback, J., Sasser, J., Carter, C. (1985): Diagnostic Characters Useful in the Identification of the Four Most Common Species of Root-Knot Nematodes (Meloidogyne Spp.). - In: Sasser J. N. et al. (eds.) An Advanced Treatise on Meloidogyne. Vol. 1. North Carolina State University, Raleigh, NC, pp. 95-112.

[27] Eisenback, J. D., Hunt, D. J. (2009): General Morphology. - In: Perry, R. N., Moens, M., Starr, J. L. (eds.) Root-Knot Nematodes. CABI, London, pp. 18-54.

[28] Elbadri, G. A., Yassin, A. M. (2010): Sesame's Protective Role in Crop Nematode Control. - In: Bedigian, D. (ed.) Sesame: The Genus Sesamum. CRC Press, Boca Raton, pp. 211218.

[29] Elmiligy, I. A., Norton, D. C. (1973): Survival and reproduction of some nematodes as affected by muck and organic acids. - Journal of Nematology 5: 50-54.

[30] El-Sayed, S., Mahdy, M. (2015): Effect of chitosan on root-knot nematode, Meloidogyne javanica on tomato plants. - International Journal of ChemTech Research 7: 1985-1992.

[31] El-Sherif, A. G., Gad, S. B., Khalil, A. M., Mohamedy, R. H. E. (2015): Impact of four organic acids on Meloidogyne Incognita infecting tomato plants under greenhouse conditions. - Global Journal of Biology, Agriculture \& Health Sciences 2: 94-100.

[32] Esser, R. P., Perry, V. G., Taylor, A. L. (1976): A diagnostic compendium of the genus Meloidogyne (Nematoda: Heteroderidae). - Proceedings of the Helminthological Society of Washington 43: 138-150.

[33] Fahramand, M., Moradi, H., Noori, M., Sobhkhizi, A., Adibian, M., Abdollahi, S., Rigi, K. (2014): Influence of humic acid on increase yield of plants and soil properties. International Journal of Farming and Allied Sciences 3: 339-341.

[34] FAO (2013): Dried Fruit. - Food \& Agriculture Organization of the United Nation, Rome.

[35] Gondal, A. S., Javed, N., Khan, S. A., Shahid, M. (2014): Use of nutritional supplements for the management of root-knot nematode (Meloidogyne incognita) infecting potato. Journal of Nematology: 46: 13-160 (abstract).

[36] Hadwiger, L. A. (2013): Multiple effects of chitosan on plant systems: solid science or hype. - Plant Science 208: 42-49.

[37] Hao, X., Papadopoulos, A. P. (1999): Effects of supplemental lighting and cover materials on growth, photosynthesis, biomass partitioning, early yield and quality of greenhouse cucumber. - Scientia Horticulturae 80: 1-18.

[38] Hartman, K. M., Sasser, J. N. (1985): Identification of Meloidogye Species on the Basis of Differential Host Test and Perineal-Pattern Morphology. - In: Sasser, J. N.et al. (eds.) An Advanced Treatise on Meloidogyne. Vol. 1. Biology and Control. North Carolina State University Graphics, Raleigh, NC, pp. 69-77.

[39] Hasabo, S. A., Noweer, E. M. A. (2005): Management of root-knot nematode Meloidogyne Incognita on eggplant with some plant extracts. - Egyptian Journal of Phytopathology 33: 65-72.

[40] Heil, M. (1999): Systemic acquired resistance: available information and open ecological questions. - Journal of Ecology 87: 341-346.

[41] Hildalgo-Diaz, L., Kerry, B. R. (2008): Integration of Biological Control with Other Methods of Nematode Management. - In: Ciancio, A., Mukerji, K. G. (eds.) Integrated Management and Biocontrol of Vegetable and Grain Crops Nematodes. Springer, Dordrecht, pp. 29-49.

[42] Hooks, C. R. R., Wang, K.-H., Ploeg, A., McSorley, R. (2010): Using marigold (Tagetes spp.) as a cover crop to protect crops from plant-parasitic nematodes. - Applied Soil Ecology 46: 307-320. 
[43] Huang, W.; Cui, J.; Liu, S.; Kong, L.; Wu, Q.; Peng, H.; He, W.; Sun, J., Peng, D. (2016): Testing various biocontrol agents against the root-knot nematode (Meloidogyne incognita) in cucumber plants identifies a combination of Syncephalastrum racemosum and Paecilomyces lilacinus as being most effective. - Biological Control 92: 31-37.

[44] Husain, S. I., Kumar, R., Khan, T. A., Titov, A. (1984): Effect of root -dip treatment of egg plant seedings with plant extracts, nematicides, oil-cake extracts and anthelmintic drugs on plant growth and root -knot development. - Pak. J. Nematol 2: 79-83.

[45] Ibrahim, S. K., Traboulsi, A. F., El-Haj, S. (2006): Effect of essential oils and plant extracts on hatching, migration and mortality of Meloidogyne incognita. - Phytopathologia Mediterranea 45: 238-246.

[46] Jones, J. T., Haegeman, A., Danchin, E. G. J., Gaur, H. S., Helder, J., Jones, M. G. K., Kikuchi, T., Manzanilla-López, R., Palomares-Rius, J. E., Wesemael, W. M. L. (2013): Top 10 plant-parasitic nematodes in molecular plant pathology. - Molecular Plant Pathology 14: 946-961.

[47] Kankam, F., Adomako, J. (2014): Influence of inoculum levels of root knot nematodes (Meloidogyne Spp.) on tomato (Solanum lycopersicum L.). - Asian Journal of Agriculture and Food Science 2: 171-178.

[48] Karssen, G., Moens, M. (2006): Root-Knot Nematodes. - In: Perry, R. N., Moens, M. (eds.) Plant Nematology. CABI, London, pp. 59-90.

[49] Kayani, M. Z., Mukhtar, T., Hussain, M. A., Ul-Haque, M. I. (2013): Infestation assessment of root-knot nematodes (Meloidogyne spp.) associated with cucumber in the Pothowar Region of Pakistan. - Crop Protection 47: 49-54.

[50] Kemei, L., Yanqiu, D., Xuesong, C. B. (2015): Occurrence and identification of root-knot nematode on greenhouse vegetables in Xinjiang. - Plant Protection 41: 191-194.

[51] Kesba, H. H., Al-Shalaby, M. E. M. (2008): Survival and reproduction of Meloidogyne incognita on tomato as affected by humic acid. - Nematology 10: 243-249.

[52] Kesba, H. H., El-Beltagi, H. S. (2012): Biochemical changes in grape rootstocks resulted from humic acid treatments in relation to nematode infection. - Asian Pacific Journal of Tropical Biomedicine 2: 287-293.

[53] Khaled, H., Fawy, H. A. (2011): Effect of different levels of humic acids on the nutrient content, plant growth, and soil properties under conditions of salinity. - Soil and Water Research 6: 21-29.

[54] Khalil, M. S., Badawy, M. E. L. (2012): Nematicidal activity of a biopolymer chitosan at different molecular weights against root-knot nematode, Meloidogyne incognita. - Plant Protection Science 48(4): 170-178.

[55] Kloepper, J. W., Reddy, M. S., Rodríguez-Kabana, R., Kenney, D. S., Kokalis-Burelle, N., Martinez-Ochoa, N., Vavrina, C. S. (2004): Application for Rhizobacteria in transplant production and yield enhancement. - Acta Horticulturae 631: 217-230.

[56] Kong, J.-O. K., Park, I.-K., Choi, K.-S., Shin, S.-C., Ahn, Y.-J. (2007): Nematicidal and propagation activities of thyme red and white oil compounds toward Bursaphelenchus xylophilus (Nematoda: Parasitaphelenchidae). - Journal of Nematology 39: 237-242.

[57] Krueger, R., Dover, K. E., McSorley, R., Wang, K. H. (2007): Marigolds (Tagetes spp.) for Nematode Management. - ENY-056 (NG045). Entomology and Nematology Department, Florida Cooperative Extension Service, Institute of Food and Agricultural Sciences, University of Florida, Gainesville, FL.

[58] Lima, E. A., Mattos, J. K., Moita, A. W., Carneiro, R. G., Carneiro, R. M. D. G. (2009): Host status of different crops for Meloidogyne ethiopica control. - Tropical Plant Pathology 34: 152-157.

[59] Machado, A. C. Z., Mattei, D., Silva, S. A., Dorigo, O. F., Ito, D. S. (2014): Host status of green manures to four species of root-knot nematodes in Brazil. - Journal of Nematology 46: 197-197. 
[60] Maheshwari, R. K., Mohan, L., Malhotra, J., Updhuay, B., Rani, B. (2014): Invigorating efficacy of Cucumis sativus for healthcare \& radiance. - International Journal of Chemistry and Pharmaceutical Sciences 2: 737-744.

[61] Malerba, M., Cerana, R. (2016): Chitosan effects on plant systems. - International Journal of Molecular Sciences 17: 1-15.

[62] Marahatta, S. P., Wang, K.-H., Sipes, B. S., Hooks, C. R. R. (2012): Effects of Tagetes patula on active and inactive stages of root-knot nematodes. - Journal of Nematology 44: 26-30.

[63] Meng, Q., Long, H., Xu, J. (2004): PCR assays for rapid and sensitive identification of three major root-knot nematodes, Meloidogyne incognita, M. javanica and M. Arenaria. Acta Phytopathologica Sinica 34: 204-210.

[64] Mesiha, F. K. (2019): Management of root rot and root knot nematode disease complex of pepper. - PhD Dissertation. Department of Plant Pathology, Faculty of Agriculture, University of Zagazig, Egypt.

[65] Mitkowski, N. A., Abawi, G. S. (2003): Root-knot nematodes. - The Plant Health Instructor 917: 1-12.

[66] Moens, M., Perry, R. N., Starr, J. L. (2009): Meloidogyne Species - A Diverse Group of Novel and Important Plant Parasites. - In: Perry, R. N., Moens, M., Starr, J. L. (eds.) RootKnot Nematodes. CABI, London.

[67] Mota, L. C. B., dos Santos, M. A. (2016): Chitin and chitosan on Meloidogyne javanica management and on chitinase activity in tomato plants. - Tropical Plant Pathology 41: 8490.

[68] Mwesige, R. (2013): Identification and pathogenicity of root-knot nematodes from tomatoes grown in Kyenjojo and Masaka Districts in Uganda. - Master of Nematology, Department of Biology, Faculty of Science, University of Gent, Gent.

[69] Natarajan, N., Cork, A., Boomathi, N., Pandi, R., Velavan, S., Dhakshnamoorthy, G. (2006): Cold aqueous extracts of african marigold, tagetes erecta for control tomato root knot nematode, Meloidogyne incognita. - Crop Protection 25: 1210-1213.

[70] Neto, C. G. T., Dantas, T. N. C., Fonseca, J. L. C., Pereira, M. R. (2005): Permeability studies in chitosan membranes. Effects of crosslinking and poly (ethylene oxide) addition. Carbohydrate Research 340: 2630-2636.

[71] Noling, J. W. (1999): Nematode Management in Cucurbits (Cucumber, Melons, Squash). University of Florida Cooperative Extension Service, Institute of Food and Agriculture Sciences, EDIS, Gainesville, FL.

[72] Ogaraku, A. O. (2007): The effect of animal manures on susceptibility of cowpea var. Moussa local to infection by root-knot nematode; Meloidogyne javanica Treub. - Pakistan Journal of Biological Sciences 10: 2980-2983.

[73] Olsen, M. W. (2011): Root-Knot Nematode. - The University of Arizona Cooperative Extension, Tuscon, AZ.

[74] Polthanee, A., Yamazaki, K. (1996): Effect of marigold (Tagetes patula L.) on parasitic nematodes of rice in Northeast Thailand. - Khon Kaen Agriculture Journal (Thailand) 24: 105-107.

[75] Powers, T. O., Harris, T. S. (1993): A polymerase chain reaction method for identification of five major Meloidogyne species. - Journal of Nematology 25: 1-6.

[76] Powers, T. O., Mullin, P. G., Harris, T. S., Sutton, L. A., Higgins, R. S. (2005): Incorporating molecular identification of Meloidogyne spp. into a large-scale regional nematode survey. - Journal of Nematology 37: 226-235.

[77] Radwan, M. A., Farrag, S. A. A., Abu-Elamayem, M. M., Ahmed, N. S. (2012): Extraction, characterization, and nematicidal activity of chitin and chitosan derived from shrimp shell wastes. - Biology and Fertility of Soils 48: 463-468.

[78] Romero, P., Dodd, I. C., Martinez-Cutillas, A. (2012): Contrasting physiological effects of partial root zone drying in field-grown grapevine (Vitis vinifera L. Cv. Monastrell) according to total soil water availability. - Journal of Experimental Botany 63: 4071-4083. 
Ismael - Mahmood: Integrated management of root-knot nematode (Meloidogyne spp.) in cucumber (Cucumis sativus L.) and its effect on nematode population density, plant growth and yield in Sulaimani Governorate, Kurdistan, Iraq -4733 -

[79] Safdar, A., Mahdi, M. M., McKenry, M. V. (2013): Organic amendments for management of root knot nematode of tunnel crops. - Journal of Nematology 45: 279-280 (abstract).

[80] Saravanapriya, B., Subramanian, S. (2005): Effect of humic acid against Meloidogyne incognita on tomato. - Annals of Plant Protection Sciences 13: 441-444.

[81] Saravanapriya, B., Subramanian, S. (2007): Management of Meloidogyne incognita on tomato with humic acid and bioinoculants. - Annals of Plant Protection Sciences 15: 195197.

[82] Sen, D., and Chatterjee, A. (2007): Phytophagous Nematodes (Order Tylenchida, Suborder Tylenchina). - In: Zoological Survey of India (ed.) Fauna of Mizoram. Zoological Survey of India, Kolkata.

[83] Shafeek, M. R., Helmy, Y. L., Omar, N. M. (2016): Effect of spraying or ground drench from humic acid on growth, total output and fruits nutritional values of cucumber (Cucumis sativus L.) grown under plastic house conditions. - International Journal of Pharm, Tech, Research 9: 52-57.

[84] Soppe, R., Saleh, R. O. (2012): Report B2.1 Historical agricultural production data in Iraq. - http://icarda.org/iraq-salinity-project/teaser 8: 1-25.

[85] Strange, R. N. (2006): Introduction to Plant Pathology. - John Wiley \& Sons, London.

[86] Swamy, S. D., Reddy, P. P., Jegowda, D. N., Swamy, B. C. (1995): Management of Meloidogyne incoginta in tomato nursery by growing trap/antagonistic crops in rotation. Current Nematology 6: 9-12.

[87] Tatlioglu, T. (1993): Cucumber (Cucumis Sativus L. - In: Kalloo, G., Bergh, B. O. (eds.) Genetic Improvement of Vegetable Crops. $7^{\text {th }}$ Ed. Pergamon Press Ltd, Oxford, UK.

[88] Taylor, D. P., Netscher, C. (1974): An improved technique for preparing perineal patterns of Meloidogyne spp. - Nematologica 20: 268-269.

[89] Taylor, A., Sasser, J. (1978): Biology, Identification and Control of Root-Knot Nematodes, North Carolina State University Graphics. - International Meloidogyne Project, USA.

[90] Temple, V., Mowbray, D., Rai, P. P., Gideon, O., Kaluwin, C., Watmelik, J. (eds.) (2015): Promoting Responsible Sustainable Development Through Science \& Technology, the PNG Way. - School of Natural and Physical Sciences, and School of Medicine and Health Sciences, University of Papua New Guinea, pp 1-18.

[91] Thomas, H. A. (1958): On Criconemoides xenoplax raski, with special reference to its biology under laboratory conditions. - Proceedings of the Helminthological Society of Washington 26: 55-59.

[92] Timper, P., Davis, R. F., Tillman, P. G. (2006): Reproduction of Meloidogyne incognita on winter cover crops used in cotton production. - Journal of Nematology 38: 83-89.

[93] Toumi, F., Waeyenberge, L., Yousef, R., Khalil, H., Al-Assas, K., Moens, M. (2014): Distribution of the root-knot nematode Meloidogyne spp., in tomato greenhouses at Lattakia and Tartus Province in Syria. - Pakistan Journal of Nematology 32: 163-172.

[94] Trudgill, D. L., Blok, V. C. (2001): Apomictic, polyphagous root-knot nematodes: exceptionally successful and damaging biotrophic root pathogens. - Annual Review of Phytopathology 39: 53-77.

[95] Tsay, T. T., Wu, S. T., Lin, Y. Y. (2004): Evaluation of asteraceae plants for control of Meloidogyne incognita. - Journal of Nematology 36: 36-41.

[96] Van De Sande-Bakhuyzen, H. L. (1928): Studies upon wheat grown under constant conditions II. - Plant Physiology 3: 7.

[97] Visser, T., Vythftingam, M. K. (1959): The effect of marigolds and some other crops on the Pratylenchus and Meloidogyne populations in tea soil. - Tea Quarterly 30: 30-38.

[98] Wehner, T. C., Maynard, D. N. (2003): Cucurbitaceae (Vine Crops). - ELS. https://doi.org/10.1038/npg.els.0003723.

[99] Weng, Y., Sun, Z. (2011): Major Cucurbit Crops. - In: Cseke, L. J., Kirakosyan, A., Kaufman, P. B., Westfall, M. V. (eds.) Handbook of Molecular and Cellular Methods in Biology and Medicine. CRC Press, Boca Raton, pp. 1-16. 
[100] Whitehead, A. G. (1968): Taxonomy of Meloidogyne (Nematodea: Heteroderidae) with descriptions of four new species. - The Transactions of the Zoological Society of London 31: 263-401.

[101] Whitehead, A. G., Hemming, J. R. (1965): A comparison of some quantitative methods of extracting small vermiform nematodes from soil. - Annals of Applied Biology 55: 25-38.

[102] Williams, L. J., Abdi, H. (2010): Fisher's Least Significant Difference (LSD) Test. - In: Salkind, N. (ed.) Encyclopedia of Research Design. Sage, Thousand Oaks, CA, pp. 1-5.

[103] XLSTAT Institute (2004): Statistical Analysis System Procedures Guide, Version 7.5. SAS Institute, Cary, NC.

[104] Yang, X., Wang, X., Wei, M., Hikosaka, S., Goto, E. (2009): Changes in growth and photosynthetic capacity of cucumber seedlings in response to nitrate stress. - Brazilian Journal of Plant Physiology 21: 309-317.

[105] Ye, W., Zeng, Y., Kerns, J. (2015): Molecular characterization and diagnosis of root-knot nematodes (Meloidogyne spp.) from turfgrasses in North Carolina, USA. - PLoS ONE 10: $1-16$.

[106] Zargar, V., Asghari, M., Dashti, A. (2015): A Review on chitin and chitosan polymers: structure, chemistry, solubility, derivatives, and applications. - Chem. Bio. Eng. Reviews 2: 204-226.

[107] Zewain, Q. k. (2014): Evaluation of some chemical nematicides and organic formulations in management of root knot nematode Meloidogyne spp. on eggplant. - Tikrit University for Agricultural Sciences. 3: 8-14.

[108] Zhuran, Q., Tianhong, L., Ning, W., Xuan, W., Hairun, Z., Hongmei, L. (2014): Occurrence and species identification of nematode parasites of vegetables and horticultural plant seedlings in export plantations. - Journal of Nanjing Agricultural University 37: 93100.

[109] Zijlstra, C., Donkers-Venne, D. T., Fargette, M. (2000): Identification of Meloidogyne incognita, $M$. javanica and $M$. arenaria using sequence characterized amplified region (SCAR)-based PCR assays. - Nematology 2: 847-885.

[110] Zinoveva, S. V., Vasyukova, N. I., Ilinskaya, L. I., Varlamov, V. P., Ozeretskovskaya, O. L., Sonin, M. D. (1999): Effect of chitosan on interactions in a plant-parasitic nematode system. - Doklady Biological Sciences 367: 400-402.

\section{APPENDICES}

Appendix 1. How to cut perineal patterns. A, B: excised female with neck region removed and body contents gently expelled; $C$ : posterior body with perineal pattern removed; D: trimming surplus cuticle around perineal pattern; E: trimmed perineal pattern ready for mounting

A
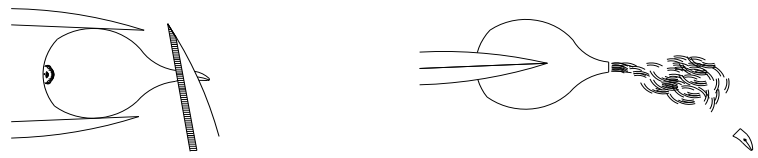

C

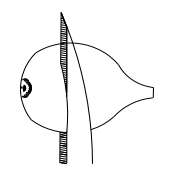

D

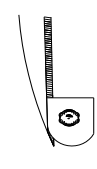

$\mathrm{E}$

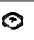




$$
\text { - } 4735 \text { - }
$$

Appendix 2. Species specific primers prepared by Sinacion, Bioscience Co. Iran

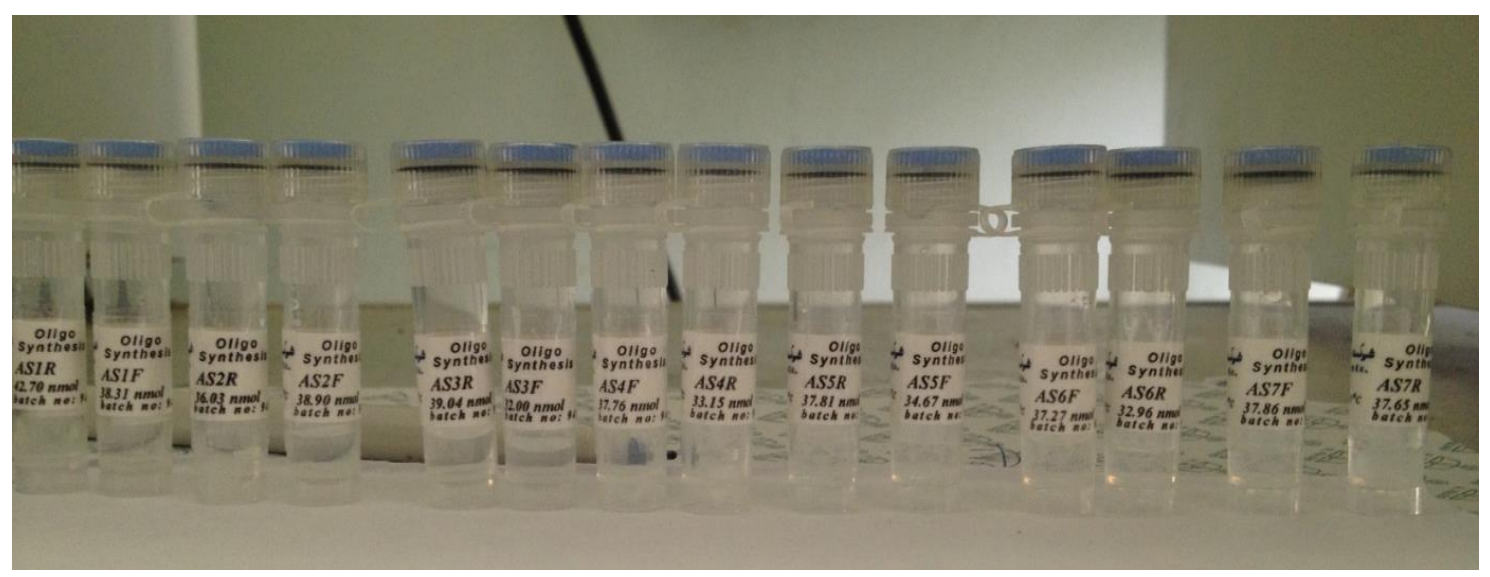

Appendix 3. MULTIGENE OptiMAX machine (PCR Thermal Cycler)

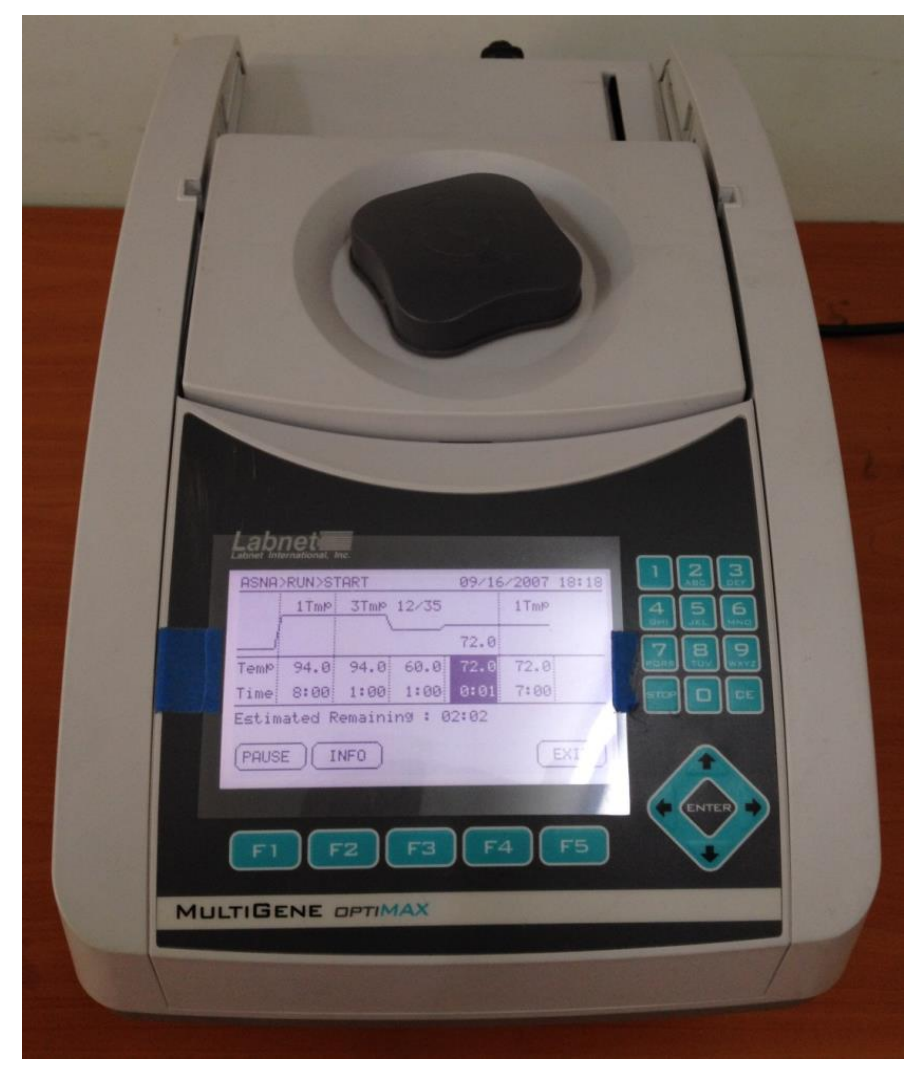

Appendix 4. PCR programs

\begin{tabular}{|c|c|c|c|c|c|c|}
\hline & Step 1 & Step 2 & Step 3 & Step4 & Step5 & Step 6 \\
\hline & $\begin{array}{c}\text { Initial } \\
\text { denaturation }\end{array}$ & Denaturation & $\begin{array}{c}\text { Annealing } \\
\text { temp. }{ }^{\circ} \mathrm{C}\end{array}$ & Extension & $\begin{array}{c}\text { Final } \\
\text { extension }\end{array}$ & Hold \\
\hline Temp. & 94.0 and 95.0 & 94.0 and 95.0 & $49.0-64.0$ & 72.0 & 72.0 & 4.00 \\
\hline Time & $8: 00$ & $30-60 \mathrm{~s}$ & $1: 00$ & 2.00 & $7: 00$ & $\infty$ \\
\hline & & \multicolumn{3}{|c|}{ Repeated for 35 cycles } & & \\
\hline
\end{tabular}


Ismael - Mahmood: Integrated management of root-knot nematode (Meloidogyne spp.) in cucumber (Cucumis sativus L.) and its effect on nematode population density, plant growth and yield in Sulaimani Governorate, Kurdistan, Iraq -4736 -

Appendix 5. Programs and different annealing temperatures were used for amplifying the DNA of the species

\begin{tabular}{|c|c|c|c|c|c|}
\hline Species & Primers & $\begin{array}{c}\text { Fragment } \\
\text { bp }\end{array}$ & \begin{tabular}{|c|} 
Denaturation \\
temperature ${ }^{\circ} \mathrm{C}$
\end{tabular} & $\begin{array}{c}\text { Annealing } \\
\text { temperature }\end{array}$ & References \\
\hline \multirow{4}{*}{$\begin{array}{c}M . \\
\text { incognita }\end{array}$} & $\begin{array}{l}\text { AS1F } \\
\text { AS1R }\end{array}$ & 1200 & 94 and 95 & $49,50,54$ and 55 & $\begin{array}{c}\text { Sinacion, Bioscience Co. Iran; } \\
\text { Zijlstra et al., 2000; Mwesige, } \\
\text { 2013; Toumi et al., 2014; Temple } \\
\text { et al., 2015; Agenbag, } 2016\end{array}$ \\
\hline & $\begin{array}{l}\text { AS2F } \\
\text { AS2R }\end{array}$ & 1350 & 94 and 95 & $49,50,54$ and 55 & $\begin{array}{l}\text { Sinacion, Bioscience Co. Iran; } \\
\text { Dong et al., 2001; Toumi et al., } \\
\text { 2014; Temple et al., } 2015\end{array}$ \\
\hline & $\begin{array}{l}\text { AS3F } \\
\text { AS3R }\end{array}$ & 399 & 94 and 95 & $\begin{array}{c}49,50,55,60 \\
\text { and } 64\end{array}$ & $\begin{array}{c}\text { Sinacion, Bioscience Co. Iran; } \\
\text { Devran et al., 2009; Toumi et al., } \\
\text { 2014; Ye et al., 2015; Agenbag, } \\
2016 \\
\end{array}$ \\
\hline & $\begin{array}{l}\text { AS4F } \\
\text { AS4R }\end{array}$ & 955 & 94 and 95 & $\begin{array}{l}49,50,55,60 \\
61,62 \text { and } 63\end{array}$ & $\begin{array}{c}\text { Sinacion, Bioscience Co. Iran } \\
\text { Devran et al., 2009; Toumi et al., } \\
\text { 2014; Chanmalee, 2014; Zhuran et } \\
\text { al., 2014; Kemei et al., 2015; } \\
\text { Agenbag, 2016 }\end{array}$ \\
\hline \multirow{3}{*}{$\begin{array}{c}M . \\
\text { javanica }\end{array}$} & $\begin{array}{l}\text { AS5F } \\
\text { AS5R }\end{array}$ & 1650 & 94 and 95 & $49,50,52$ and 55 & $\begin{array}{l}\text { Sinacion, Bioscience Co. Iran; } \\
\text { Dong et al., 2001; Devran et al., } \\
\text { 2009; Toumi et al., } 2014\end{array}$ \\
\hline & $\begin{array}{l}\text { AS6F } \\
\text { AS6R }\end{array}$ & 670 & 94 and 95 & $\begin{array}{c}49,50,55,60 \\
63 \text { and } 64\end{array}$ & $\begin{array}{c}\text { Sinacion, Bioscience Co. Iran; } \\
\text { Zijlstra et al., 2000; Devran et al., } \\
\text { 2009; Toumi et al., 2014; } \\
\text { Chanmalee, 2014; Aydinli and } \\
\text { Mennan, 2016 }\end{array}$ \\
\hline & $\begin{array}{l}\text { AS7F } \\
\text { AS7R }\end{array}$ & 517 & 94 and 95 & $\begin{array}{l}49,50,55,61 \\
\text { and } 62\end{array}$ & $\begin{array}{c}\text { Sinacion, Bioscience Co. Iran; } \\
\text { Zhuran et al., 2014; Toumi et al., } \\
\text { 2014; Kemei et al., } 2015\end{array}$ \\
\hline
\end{tabular}

Appendix 6. Electrophoresis chamber (power supply and the tray)

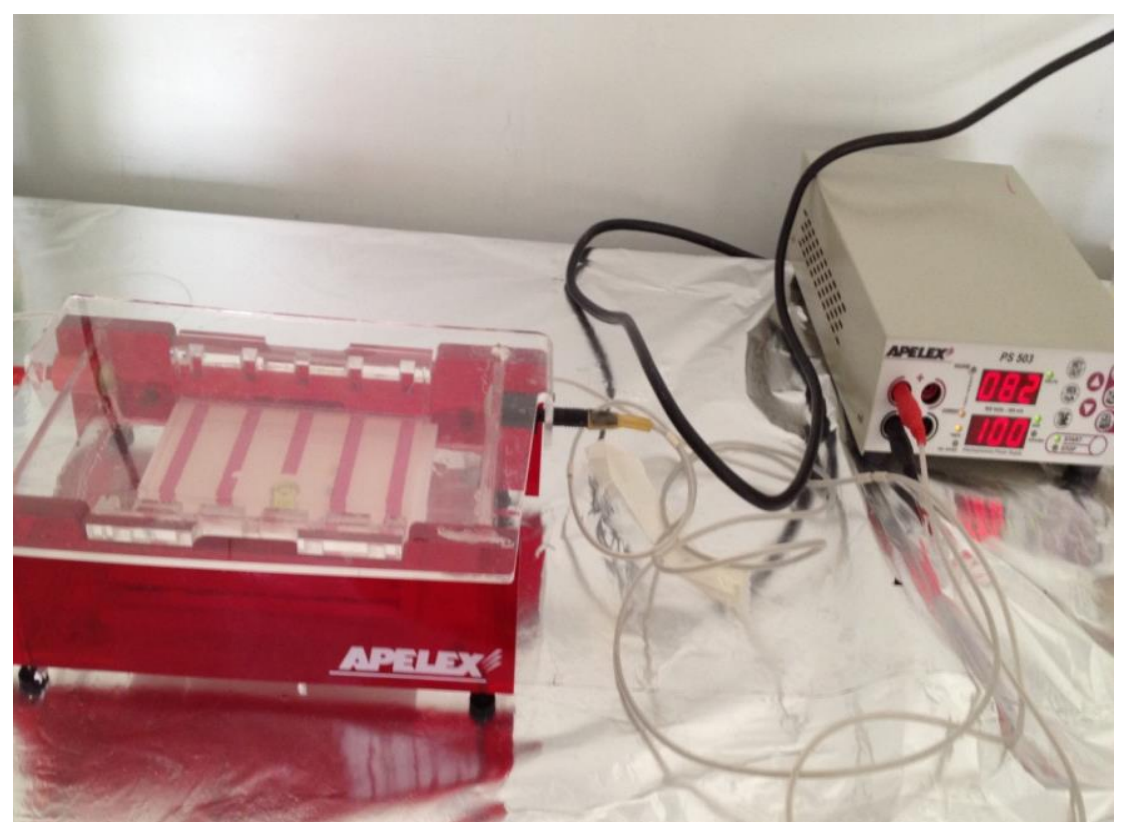




$$
-4737 \text { - }
$$

\section{Appendix 7. UV transilluminator}

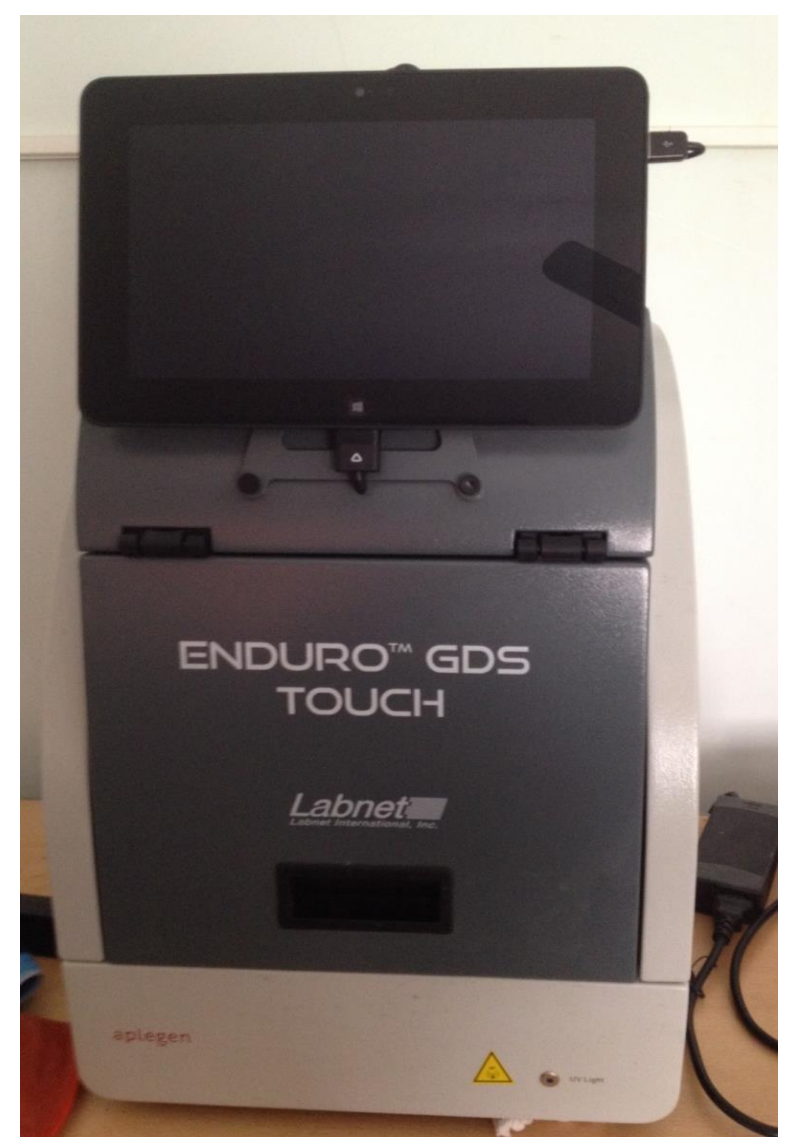

Appendix 8. Extraction-tray models for isolating the nematodes (Juveniles 2) (original)
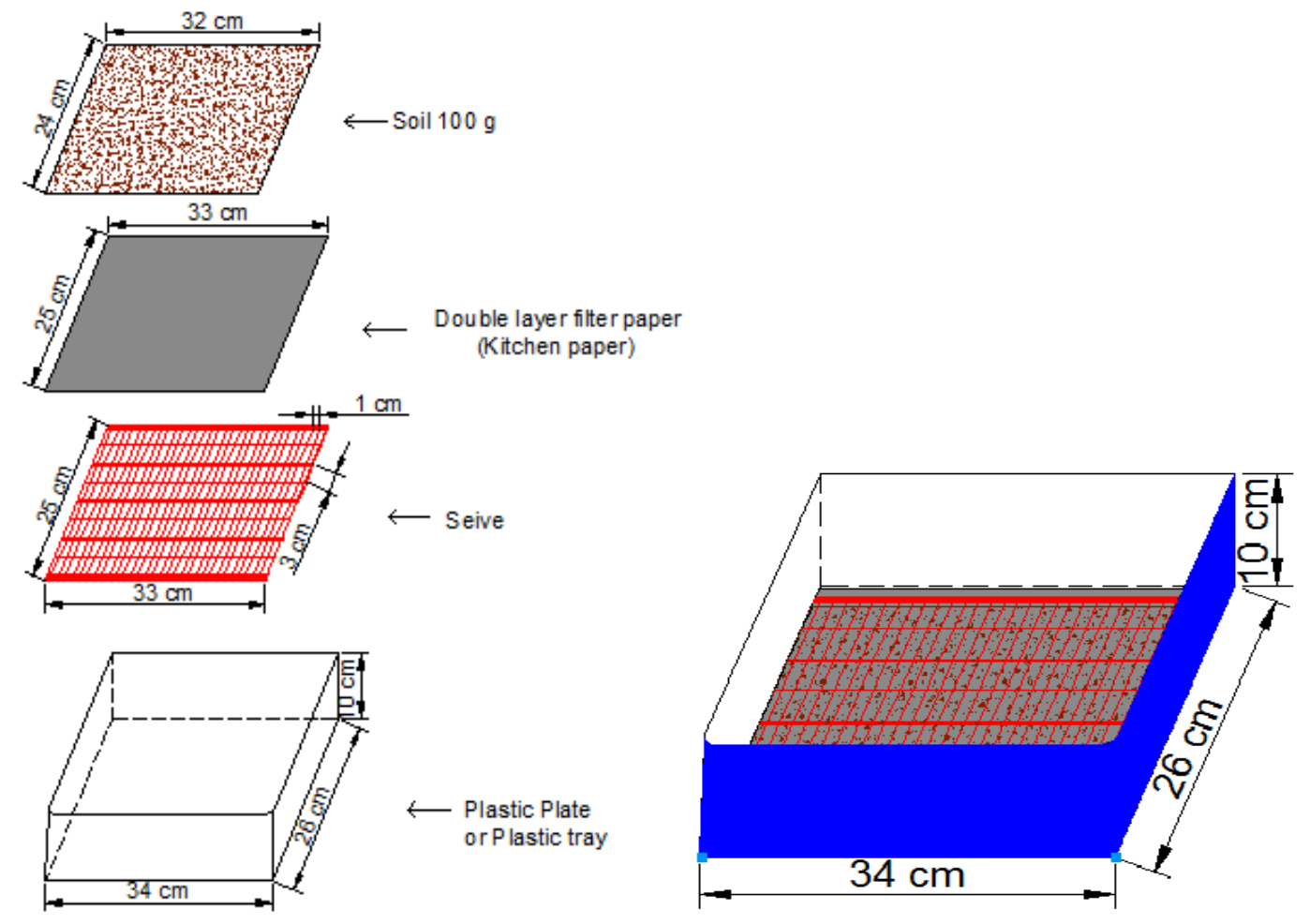

APPLIED ECOLOGY AND ENVIRONMENTAL RESEARCH 18(3):4709-4741.

http://www.aloki.hu • ISSN 15891623 (Print) • ISSN 17850037 (Online)

DOI: http://dx.doi.org/10.15666/aeer/1803_47094741

(c) 2020, ALÖKI Kft., Budapest, Hungary 
Appendix 9. Counting dish designed for calculating the nematodes (Juveniles 2) (original)

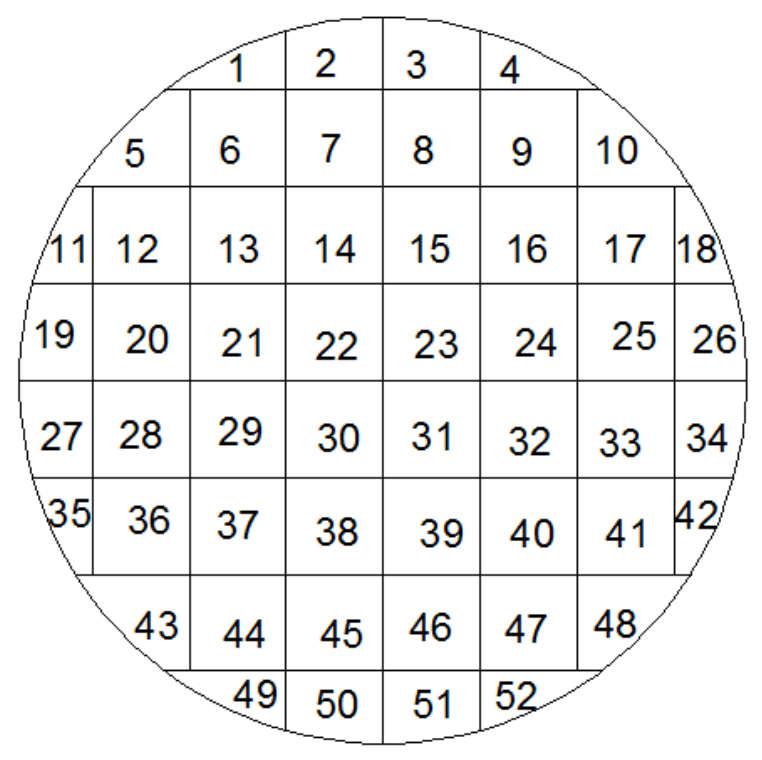

Appendix 10. The tube of ladder and its information paper by Sinacion company-Iran

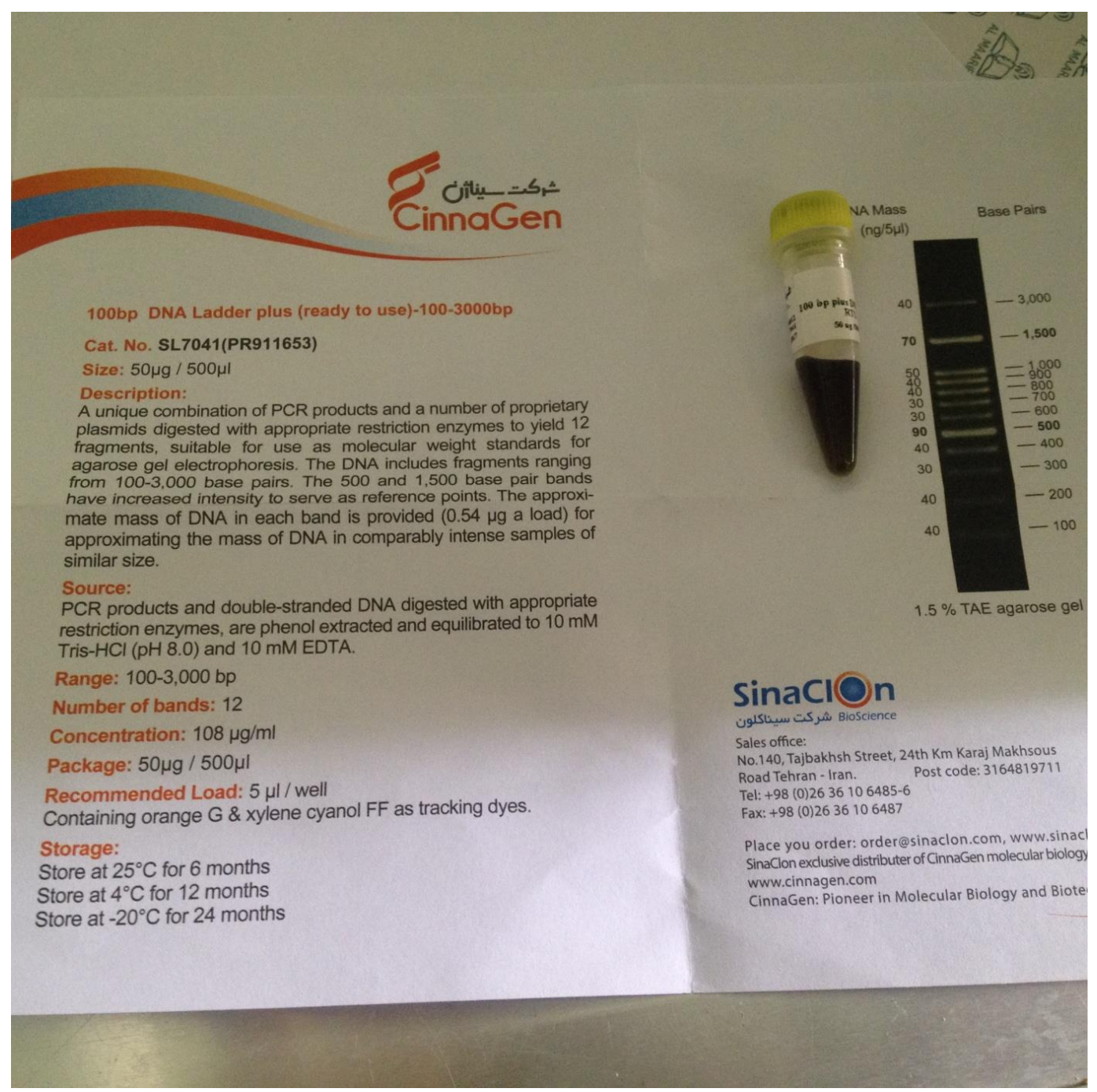

APPLIED ECOLOGY AND ENVIRONMENTAL RESEARCH 18(3):4709-4741.

http://www.aloki.hu • ISSN 15891623 (Print) • ISSN 17850037 (Online)

DOI: http://dx.doi.org/10.15666/aeer/1803_47094741

(c) 2020, ALÖKI Kft., Budapest, Hungary 
Appendix 11. (A) The device of thermo Scientific Nanodrop 2000C. (B) The concentration and purity diagram of Meloidogyne spp. DNA extraction as tested by Nanodrop 2000C device

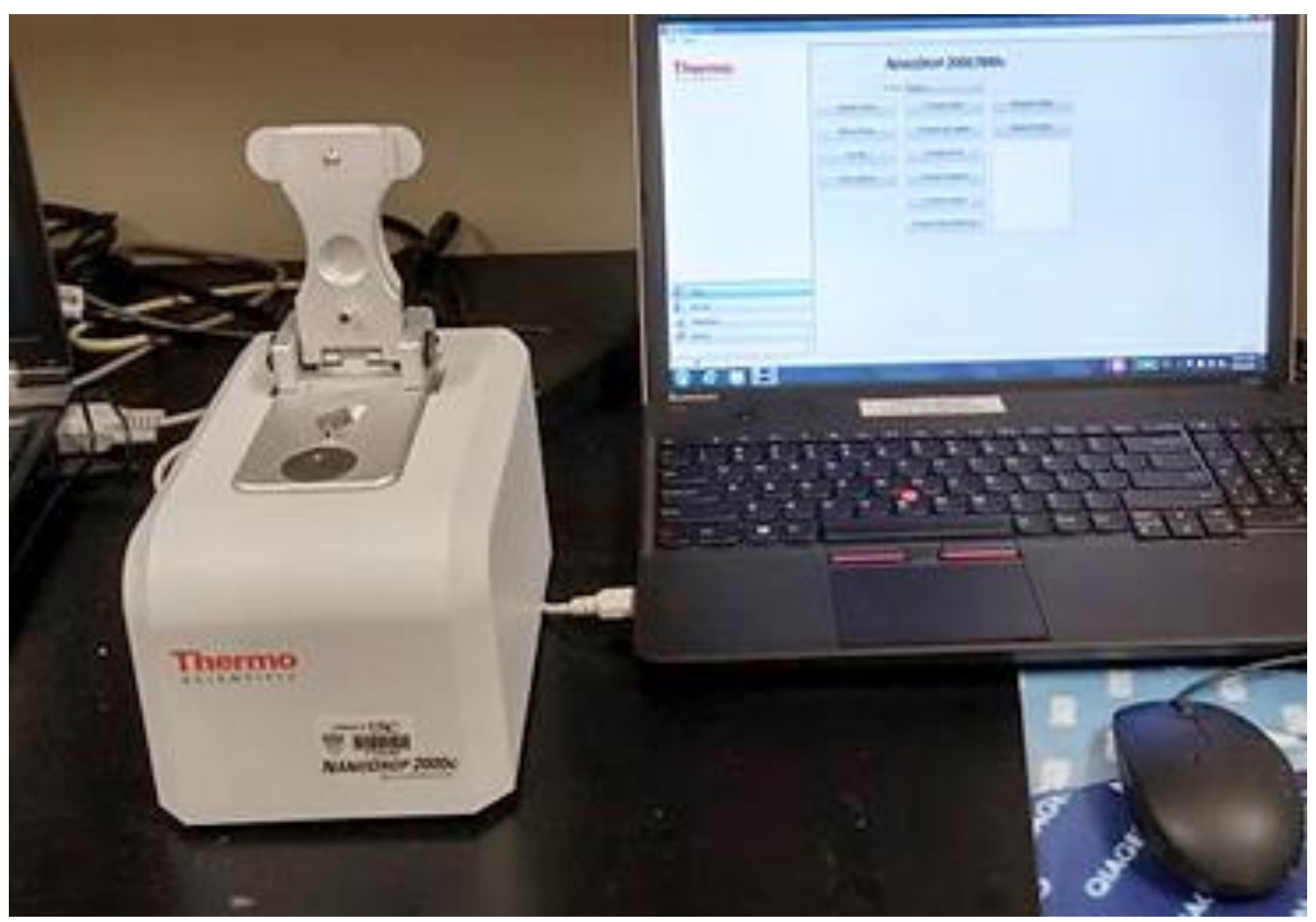

A

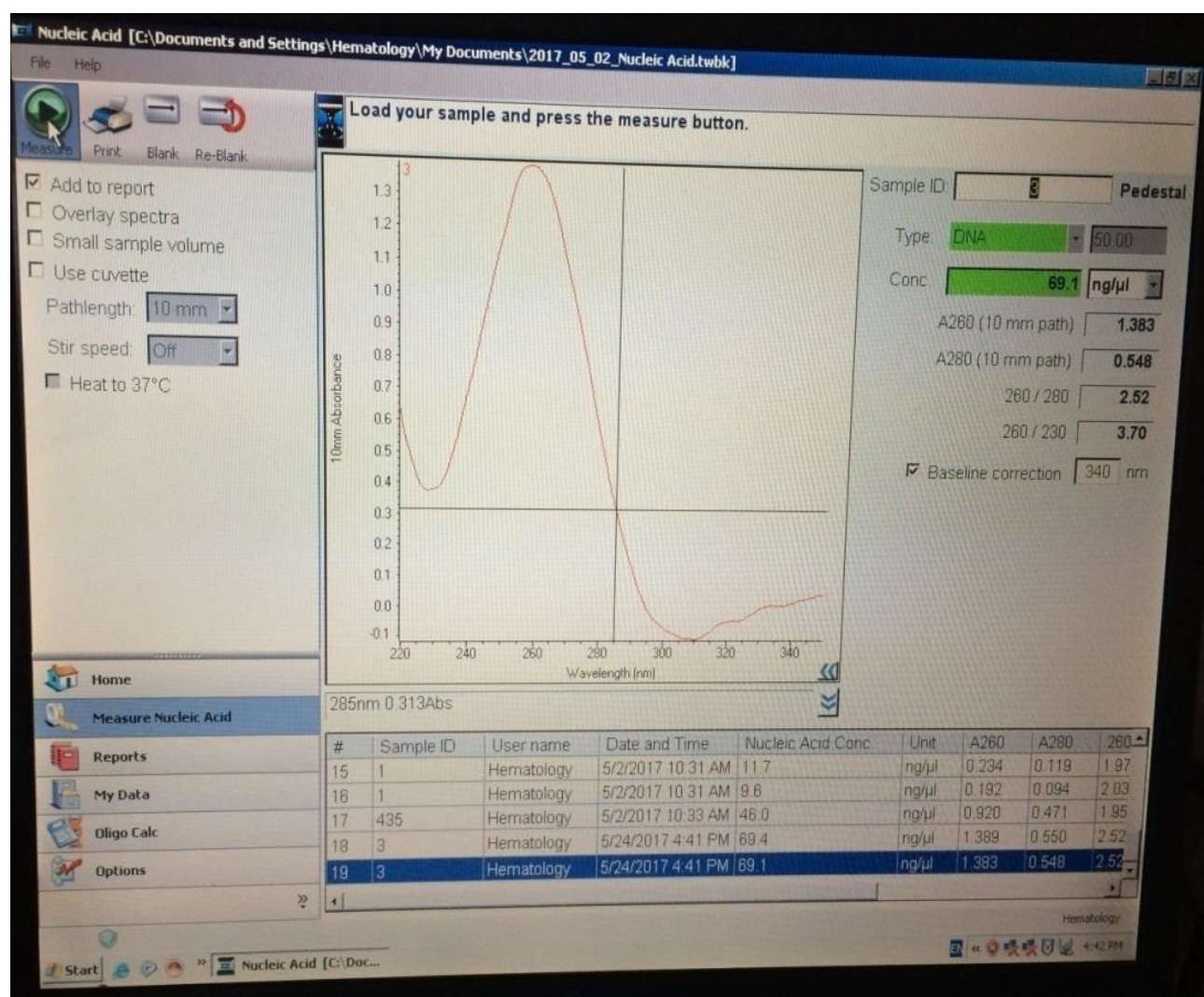


Ismael - Mahmood: Integrated management of root-knot nematode (Meloidogyne spp.) in cucumber (Cucumis sativus L.) and its effect on nematode population density, plant growth and yield in Sulaimani Governorate, Kurdistan, Iraq -4740 -

Appendix 12. Analysis of variance including degree of freedom (df) and mean squares of replication, treatments and error for Population densities (Juveniles 2) / $100 \mathrm{~g}$ soil and number of galls

\begin{tabular}{c|c|c|c}
\hline \multirow{2}{*}{ Characters } & Replications & Treatments & Error \\
\cline { 2 - 4 } & $\mathbf{( d . f = 2 )}$ & $\mathbf{( d . f = 8 )}$ & $\mathbf{( d . f = 1 6 )}$ \\
\cline { 2 - 4 } & Mean square & Mean square & Mean square \\
\hline One day before of applying treatments $(\mathrm{Pi})$ & 13980.778 & $1979.500 \mathrm{NS}$ & 3455.944 \\
After 10 days of application & 51674.704 & $46246.315 \mathrm{NS}$ & 54210.204 \\
After 20 days of application & 126899.593 & $46380.759 \mathrm{NS}$ & 72008.676 \\
After 30 days of application (Pf) & 3831.148 & $83707.037 * *$ & 2182.773 \\
Number of the galls (P $\leq 0.05)$ & 771.797 & $1569.273^{* *}$ & 222.680 \\
Number of the galls $(\mathrm{P} \leq 0.01)$ & 771.797 & $1569.273^{*}$ & 222.680 \\
\hline
\end{tabular}

* indicates significant difference at $\mathrm{P} \leq 0.05$, ** indicates high significant difference at $\mathrm{P} \leq 0.05$ and $\mathrm{Ns}$ indicates non-significant difference

Appendix 13. Analysis of variance including degree of freedom (df) and mean squares of replication, treatments and error for some plant growth parameters (vegetative parts) of cucumber (cv. Naseem F1)

\begin{tabular}{|c|c|c|c|}
\hline \multirow{3}{*}{ Characters } & Replications & Treatments & Error \\
\hline & $($ d.f $=2)$ & $(\mathrm{d} . \mathrm{f}=\mathbf{8})$ & $(d . f=16)$ \\
\hline & Mean square & Mean square & Mean square \\
\hline Plant height $(\mathrm{cm})$ & 0.138 & $0.420 * *$ & 0.020 \\
\hline Stem diameter $(\mathrm{cm})$ & 0.658 & $1.186^{* *}$ & 0.108 \\
\hline No. of nodes. plant ${ }^{-1}$ & 21.333 & $164.833^{* *}$ & 1.583 \\
\hline No. of leaves. plant ${ }^{-1}$ & 11.704 & $198.009 \mathrm{NS}$ & 20.912 \\
\hline Fresh plant weight (vegetable parts) g. plant ${ }^{-1}$ & 10901.248 & $25751.528^{*}$ & 3124.286 \\
\hline Leaf area. plant ${ }^{-1}\left(\mathrm{~cm}^{2}\right)$ & 3402.690 & $1456.129 *$ & 411.055 \\
\hline
\end{tabular}

* indicates significant difference at $\mathrm{P} \leq 0.05$, ** indicates high significant difference at $\mathrm{P} \leq 0.05$ and Ns indicates non-significant difference

Appendix 14. Analysis of variance including degree of freedom (df) and mean squares of replication, treatments and error for some plant growth (root parts) of cucumber (cv. Naseem F1)

\begin{tabular}{c|c|c|c}
\hline \multirow{2}{*}{ Characters } & Replications & Treatments & Error \\
\cline { 2 - 4 } & $\mathbf{( d . f = 2 )}$ & $\mathbf{( d . f = 8 )}$ & $\mathbf{( d . f = 1 6 )}$ \\
\cline { 2 - 4 } & Mean square & Mean square & Mean square \\
\hline Root length $(\mathrm{cm})$ & 11.576 & $18.532^{*}$ & 6.530 \\
Fresh root weight $(\mathrm{g})$ & 78.390 & $23.188^{*}$ & 6.146 \\
Dried root weight $(\mathrm{g})$ & 13.863 & $31.973^{* *}$ & 0.988 \\
\hline
\end{tabular}

* indicates significant difference at $\mathrm{P} \leq 0.05$, ** indicates high significant difference at $\mathrm{P} \leq 0.05$ and $\mathrm{Ns}$ indicates non-significant difference 
Appendix 15. Analysis of variance including degree of freedom ( $d f)$ and mean squares of replication, treatments and error for some plant content of cucumber (cv. Naseem F1)

\begin{tabular}{c|c|c|c}
\hline \multirow{2}{*}{ Characters } & Replications & Treatments & Error \\
\cline { 2 - 4 } & $(\mathbf{d . f}=\mathbf{2})$ & $(\mathbf{d . f}=\mathbf{8})$ & $(\mathbf{d . f}=\mathbf{1 6})$ \\
\cline { 2 - 4 } & Mean square & Mean square & Mean square \\
\hline Intensity of leaf chlorophyll (SPAD unit) & 18.498 & $46.605^{* *}$ & 3.707 \\
\% of the Nitrogen (N) content in the leaf dry weight & 0.034 & $0.060^{*}$ & 0.022 \\
\% of the Phosphor (P) content in the leaf dry weight & 0.011 & $0.001 \mathrm{NS}$ & 0.002 \\
\% of the Potassium (K) content in the leaf dry weight & 0.097 & $0.046 \mathrm{NS}$ & 0.087 \\
\hline
\end{tabular}

$*$ indicates significant difference at $\mathrm{P} \leq 0.05$, ** indicates high significant difference at $\mathrm{P} \leq 0.05$ and Ns indicates non-significant difference

Appendix 16. Analysis of variance including degree of freedom (df) and mean squares of replication, treatments and error for floral growth

\begin{tabular}{|c|c|c|c|}
\hline \multirow{3}{*}{ Characters } & Replications & Treatments & Error \\
\hline & $(\mathrm{d} . \mathrm{f}=2)$ & $(\mathrm{d} . \mathrm{f}=8)$ & $(d . f=16)$ \\
\hline & Mean square & Mean square & Mean square \\
\hline No. of flowers. plant ${ }^{-1}$ & 132.333 & $14.333^{*}$ & 2.083 \\
\hline No. of aborted flowers. plant ${ }^{-1}$ & 330.581 & $25.753 \mathrm{NS}$ & 17.356 \\
\hline No. of fruit. plant ${ }^{-1}$ & 179.593 & $71.759^{*}$ & 4.176 \\
\hline Fresh weight of fruit. plant ${ }^{-1}(\mathrm{~g})$ & 179.505 & $43.718 \mathrm{NS}$ & 38.041 \\
\hline Diameter of fruits. plant ${ }^{-1}(\mathrm{~cm})$ & 0.032 & $0.365 \mathrm{NS}$ & 0.007 \\
\hline Length of fruits $(\mathrm{cm})$ & 0.955 & $0.979 \mathrm{NS}$ & 0.243 \\
\hline Fruit moisture content $(\%)$ & 0.593 & $0.690 \mathrm{NS}$ & 0.141 \\
\hline
\end{tabular}

* indicates significant difference at $\mathrm{P} \leq 0.05$, ** indicates high significant difference at $\mathrm{P} \leq 0.05$ and Ns indicates non-significant difference

Appendix 17. Analysis of variance including degree of freedom ( $d f)$ and mean squares of replication, treatments and error for yield

\begin{tabular}{c|c|c|c}
\hline \multirow{2}{*}{ Characters } & Replications & Treatments & Error \\
\cline { 2 - 4 } & $\mathbf{( d . f = 2 )}$ & $(\mathbf{d} . \mathbf{f}=\mathbf{8})$ & $(\mathbf{d . f}=\mathbf{1 6})$ \\
\cline { 2 - 4 } & Mean square & Mean square & Mean square \\
\hline Early yield $\left(\mathrm{kg} . \mathrm{plant}^{-1}\right)$ & 0.019 & $0.182 \mathrm{NS}$ & 0.211 \\
Total yield $\left(\mathrm{kg} . \mathrm{plant}^{-1}\right)$ & 4.972 & $4.234^{*}$ & 0.781 \\
\hline
\end{tabular}

$*$ indicates significant difference at $\mathrm{P} \leq 0.05$, ** indicates high significant difference at $\mathrm{P} \leq 0.05$ and Ns indicates non-significant difference 